\title{
Metabolomic Profiles of Dinophysis acuminata and Dinophysis acuta Using Non-Targeted High-Resolution Mass Spectrometry: Effect of Nutritional Status and Prey
}

\author{
María García-Portela ${ }^{1, *}$ (1) , Beatriz Reguera ${ }^{1}$ (D), Manoella Sibat ${ }^{2}$ (D), Andreas Altenburger ${ }^{3}$ (1), \\ Francisco Rodríguez ${ }^{1}$ and Philipp Hess ${ }^{2}$ (i) \\ 1 IEO, Oceanographic Centre of Vigo, Subida a Radio Faro 50, Vigo 36390, Spain; beatriz.reguera@ieo.es (B.R.); \\ francisco.rodriguez@ieo.es (F.R.) \\ 2 IFREMER, Phycotoxins Laboratory, rue de l'Ile d'Yeu, BP 21105, F-44311 Nantes, France; \\ manoella.sibat@ifremer.fr (M.S.); philipp.hess@ifremer.fr (P.H.) \\ 3 Natural History Museum of Denmark, University of Copenhagen, Øster Voldgade 5-7, 1350 Copenhagen, \\ Denmark; aaltenburger@snm.ku.dk \\ * Correspondence: maria.garcia@ieo.es; Tel.: +34-986-462-273
}

Received: 14 February 2018; Accepted: 20 April 2018; Published: 26 April 2018

\begin{abstract}
Photosynthetic species of the genus Dinophysis are obligate mixotrophs with temporary plastids (kleptoplastids) that are acquired from the ciliate Mesodinium rubrum, which feeds on cryptophytes of the Teleaulax-Plagioselmis-Geminigera clade. A metabolomic study of the three-species food chain Dinophysis-Mesodinium-Teleaulax was carried out using mass spectrometric analysis of extracts of batch-cultured cells of each level of that food chain. The main goal was to compare the metabolomic expression of Galician strains of Dinophysis acuminata and D. acuta that were subjected to different feeding regimes (well-fed and prey-limited) and feeding on two Mesodinium (Spanish and Danish) strains. Both Dinophysis species were able to grow while feeding on both Mesodinium strains, although differences in growth rates were observed. Toxin and metabolomic profiles of the two Dinophysis species were significantly different, and also varied between different feeding regimes and different prey organisms. Furthermore, significantly different metabolomes were expressed by a strain of D. acuminata that was feeding on different strains of the ciliate Mesodinium rubrum. Both species-specific metabolites and those common to D. acuminata and D. acuta were tentatively identified by screening of METLIN and Marine Natural Products Dictionary databases. This first metabolomic study applied to Dinophysis acuminata and D.acuta in culture establishes a basis for the chemical inventory of these species.
\end{abstract}

Keywords: Dinophysis physiology; lipophilic toxins; non-targeted analysis; metabolomics

\section{Introduction}

Dinophysis species produce diarrhetic shellfish poisoning (DSP) toxins and pectenotoxins (PTXs) and pose a major concern to public health and the aquaculture industry in Western Europe [1,2]. Their impact is particularly serious in the Galician Rías Baixas (NW Spain), site of intensive mussel (Mytilus galloprovincialis) production (up to $3 \times 10^{5}$ metric tons per year; [3]). In this region, recurrent spring-summer proliferations of D. acuminata, followed in some years by those of D. acuta, cause lengthy harvesting bans whenever toxins in shellfish exceed regulatory levels [4]. Even though Dinophysis toxins (DTXs) emerged as a major risk since the 1970s, it was not until the recent cultivation of D. acuminata in the laboratory [5] that it became possible to undertake physiological studies of the 
growth and the toxin production dynamics of this organism. Dinophysis species are obligate mixotrophs that need light, nutrients, and live prey to survive and grow [6-8]. The feeding mechanism (earlier discovered by Hansen [9]) in Phalacroma rotundatum and D. hastata feeding on the ciliate Tiarina fusus) is a kind of phagocytosis (myzocytosis) where the prey content is sucked into the predator cell through a feeding peduncle. A similar structure is used by D. acuminata and D. acuta to feed on M. rubrum from which they temporarily retain its plastids (known as kleptoplastids) [10]. García-Cuetos et al. [11] argued that Dinophysis contained permanent plastids due to the different disposition of their thylakoids and the observation of a third membrane, in contrast with the four-membrane plastids of M. rubrum. Later publications however showed that these plastids are temporary and managed in different ways depending on the cryptophyte source $[7,12,13]$. Field studies have confirmed that T. amphioxeia and other Teleaulax species are the most common source of plastids in Dinophysis [14-20]. Nevertheless, the possibility of other kleptoplastid-bearing ciliate species (different from Mesodinium) acting as vectors of Teleaulax-like plastids to Dinophysis should not be excluded. This is supported by the finding of plastids from multiple algal sources in Dinophysis from Korean waters [17], and led other authors to hypothesize that different plastid-retaining oligotrichous ciliates, such as Cyrtostrombidium, Laboea, Strombidium, and Tontonia [21] could be alternative prey for Dinophysis [22]. Mesodinium rubrum is a phototrophic ciliate that feeds on cryptophytes [23] and retains their plastids and mitochondria [10,24]. The nature of this consortium has been a matter of debate over the last decade [25,26]. Mesodinium rubrum is able to feed on different cryptophyte genera, but higher growth rates in cultures are observed when species of the Teleaulax/Plagioselmis/Geminigera complex are added as prey [25,27]. Furthermore, whether there is a Dinophysis-specific selection or different growth response to different species (e.g., M. major), or even strains of Mesodinium remains an open question.

Recently, metabolomics has been introduced as a new approach to help in the understanding of metabolic characteristics, elucidating metabolic mechanisms and identifying metabolic biomarkers in a vast array of organisms [28]. Metabolome designates the array of metabolites, i.e., intra- and extracellular molecules resulting from enzymatic reactions, which a living organism is able to produce. Thus, a metabolome can be considered as a phenotypical expression, i.e., a chemical "snapshot" of an organism at a specific time, and is likely to change depending on external conditions [29,30]. Therefore, results that were observed in one single experiment should not be extrapolated to field conditions or other experiments, even when using the same species.

Studies on microalgae that are based on metabolomic analyses using mass spectrometry-based techniques are scarce and most of them have been carried out with diatoms [29]. Research on bioactive compounds in marine dinoflagellates has usually been related either to toxin production or pigments [31]. Metabolomics is a powerful screening tool to detect new compounds produced by these microalgae, including new toxins; to characterize them with their environment (environmental metabolomics, [32]); and, to describe their response to different stressors, such as climate change, and pollution [33]. It may be a suitable technique to identify differences and/or similarities between different strains of the same species [34], or to track species in different environments [35]. In the particular case of Dinophysis species, metabolomics may be helpful to understand similar and different behavioral traits between D. acuta and D. acuminata, the most relevant toxigenic species of Dinophysis in Western European coastal waters.

Some secondary metabolites of dinoflagellates, including lipophilic toxins, were first described as being produced by sponges. For instance, Tachibana et al. [36] isolated okadaic acid (OA) from the sponges Halichondria okadai and H. melanodocia, but suggested that OA could originate from a microorganism. This hypothesis was confirmed later by Murakami et al. [37], who identified OA production in the epibenthic dinoflagellate Prorocentrum lima. Antifungal extracellular metabolites, which inhibit the growth of Aspergillus niger, have been found in cultures of Gambierdiscus toxicus [38]. Anticancer compounds, such as a sulphated polysaccharide (GA3P), were isolated from Gymnodinium species [39,40], and amphidinolide H [41] and carbenolide [42] from Amphidinium sp. 
The present study aimed to identify similarities and differences between the metabolomes of D. acuta and D. acuminata fed two strains of M. rubrum under different nutritional status (well-fed/prey limited) through non-targeted analysis with ultra-high-performance liquid chromatography (UHPLC) coupled to high resolution mass spectrometry (HRMS). Metabolites tentatively identified by screening of their mass against the Marine Natural Products Dictionary [43] or METLIN [44] were associated with specific culture conditions, and could be used as biochemical markers of both physiological conditions and species-specific responses to transient environmental conditions. This is the first time that metabolomic techniques were applied to study Dinophysis.

\section{Results}

\subsection{Phylogenetic Analysis}

The phylogenetic analysis of M. rubrum was consistent with previous findings and showed four distinct clades that were represented by the Mesodinium rubrum complex, M. chamaeleon, M. pulex, and M. pupula [28,45]. The newly sequenced Danish (MrDK-2009) SSU-rDNA showed a 99.7\% pairwise sequence identity with that of the Spanish (AND-A0711) strain (Figure 1).

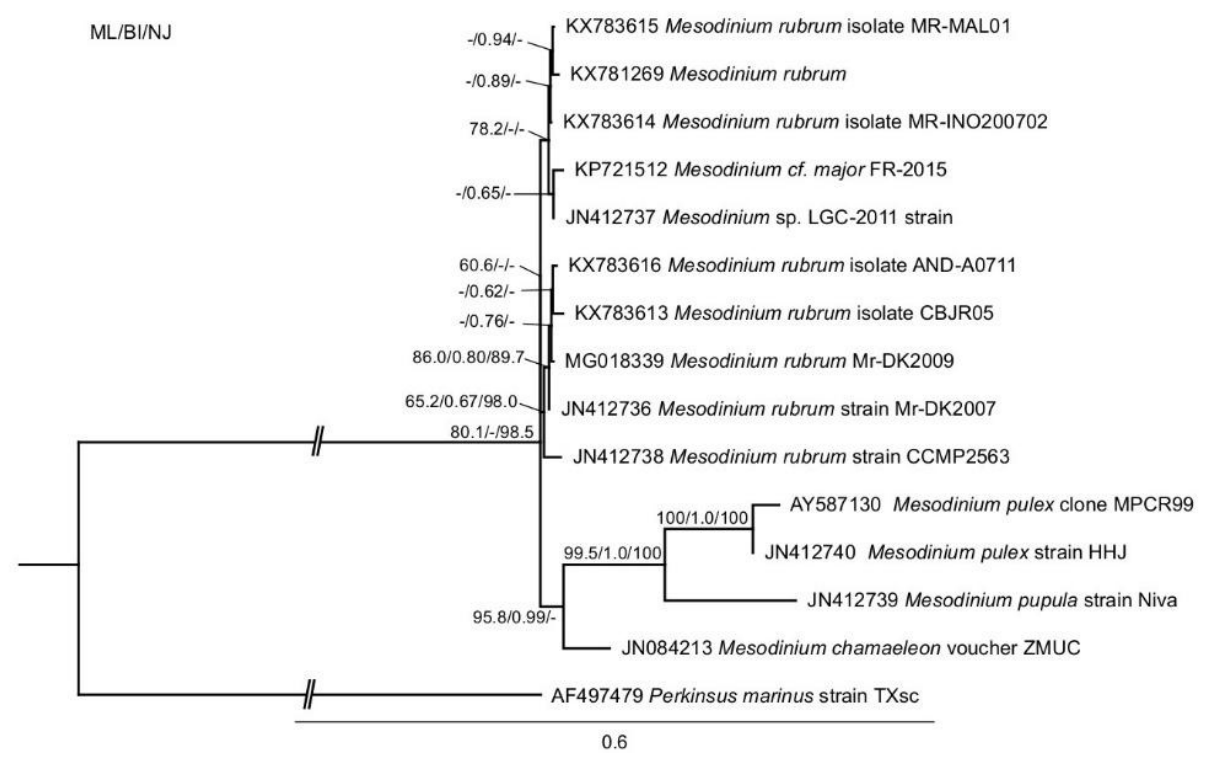

Figure 1. Phylogeny of Mesodinium inferred by maximum likelihood analysis of SSU-rDNA sequences. Numbers at nodes represent the bootstrap values of maximum likelihood out of 1000 replicates; the posterior probability of Bayesian analysis; and, the bootstrap values of neighbor-joining out of 10,000 replicates. Not resolved branches are marked with minus (-). The scale bar corresponds to six substitutions per 100 nucleotide positions. The branch to the out-group is not to scale.

\subsection{Growth Curves}

During the first phase of Experiment 2, all the triplicate flasks of well-fed Dinophysis still contained Mesodinium cells after seven days. Maximal specific growth rates $\left(\mu_{0-7}\right)$ and yield were found in cultures of D. acuminata fed Danish $\left(0.42\right.$ day $^{-1} ; 1.2 \times 10^{3}$ cells L $\left.^{-1}\right)$ and Spanish $\left(0.32\right.$ day $^{-1}$; 500 cells $\mathrm{L}^{-1}$ ) Mesodinium. Lower values were obtained in the case of $D$. acuta fed either Danish $\left(0.27 \mathrm{~d}^{-1} ; 500\right.$ cells $\left.\mathrm{L}^{-1}\right)$ or Spanish $\left(0.18\right.$ day $^{-1} ; 200$ cells $\left.\mathrm{L}^{-1}\right)$ Mesodinium (Figure 2A,B).

During the second phase of Experiment 2, ciliates were exhausted by day 7 in all the triplicate flasks, except those of D. acuta fed Danish M. rubrum (Figure 2C,D). Results on specific growth rates and yields showed maximal values for D. acuminata fed Danish $M$. rubrum $\left(\mu_{0-8}=0.25\right.$ day $\left.^{-1}\right)$. Nevertheless, D. acuminata fed Spanish M. rubrum $\left(\mu_{0-10}=0.08\right.$ day $\left.^{-1}\right)$ and $D$. acuta fed Danish M. rubrum $\left(\mu_{4-8}=0.08\right.$ day $\left.^{-1}\right)$ had a very poor growth and D. acuta fed Spanish M. rubrum had hardly 
any growth $\left(\mu_{6-10}=0.07\right.$ day $\left.^{-1}\right)$. Thus, $D$. acuta did not seem to feed well on Danish ciliate prey and culture densities declined from day 10 onwards. The opposite was observed in D. acuminata, which reached a density of $\sim 2200$ cells $\mathrm{mL}^{-1}$ by the end of Experiment 2 (Figure $2 \mathrm{C}$ ).

The biomass of D. acuta and Danish M. rubrum harvested for toxins and other analyses on the second phase of Experiment 2 represented $81.6 \pm 4.0 \%$ and $18.4 \pm 4.0 \%$ of the total pellet biomass, respectively. In contrast, during the first phase of Experiment 2 these percentages were $93.5 \pm 1.4 \%$ and $6.5 \pm 1.4 \%$ for D. acuta and Danish M. rubrum, respectively, D. acuta being well fed in both situations (Table 1).

\section{D. acuminata}
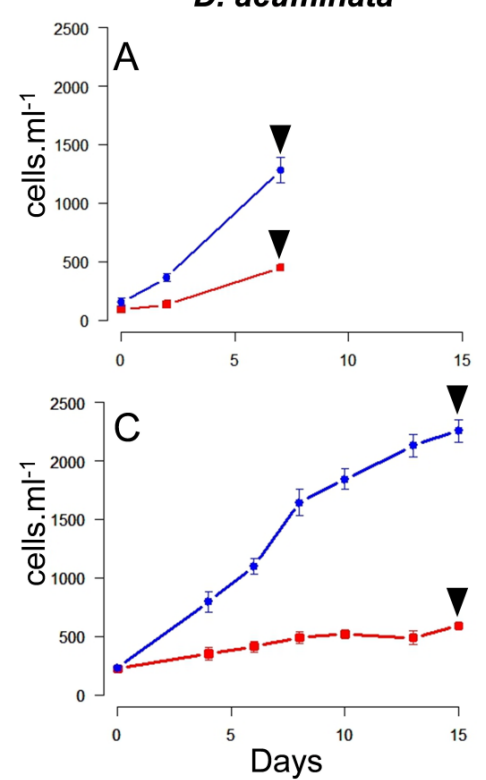

\section{D. acuta}
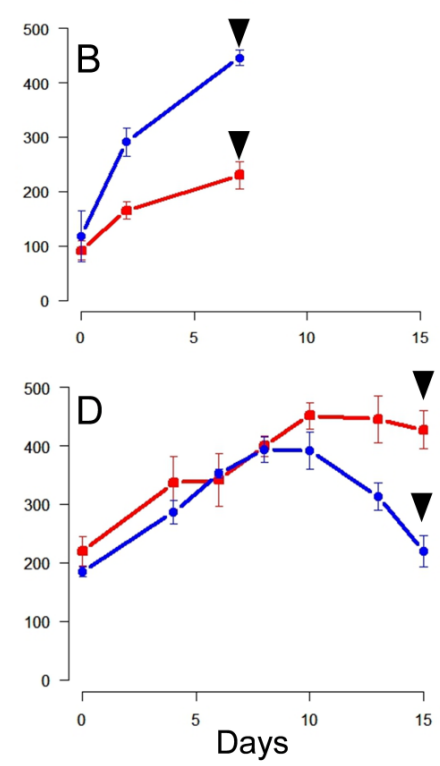

Figure 2. Growth curves during the first $(\mathbf{A}, \mathbf{B})$ and second $(\mathbf{C}, \mathbf{D})$ phase of Experiment 2. Dinophysis acuminata (A,C); D. acuta (B,D). Arrows indicate the harvesting day, blue and red lines correspond to Dinophysis cells fed Spanish and Danish Mesodinium rubrum, respectively. (Notice the different scale in the $Y$-axis for both species).

Table 1. Composition and collection day of the pellets obtained from Experiment 2.

\begin{tabular}{|c|c|c|c|c|c|c|}
\hline \multirow{2}{*}{ Sample } & \multirow{2}{*}{ Day } & \multirow{2}{*}{ Cells (N) \pm Std Dev. } & \multicolumn{3}{|c|}{ Pellet Biomass \% Average } & \multirow{2}{*}{ Volume (mL) } \\
\hline & & & Dinophysis & M. rubrum & T. amphioxeia & \\
\hline T. amphioxeia & 3 & $283,333 \pm 28,867$ & & & 100 & 10 \\
\hline Danish M. rubrum & 7 & $89,500 \pm 866$ & & 100 & & 15 \\
\hline Spanish M. rubrum & 7 & $80,000 \pm 8660$ & & 100 & & 30 \\
\hline $\begin{array}{l}\text { D. acuta }+ \text { Danish } \\
\text { M. rubrum }\end{array}$ & 7 & $40,140 \pm 1247$ & 93.48 & 6.52 & & 90 \\
\hline $\begin{array}{l}\text { D. acuta }+ \text { Spanish } \\
\text { M. rubrum }\end{array}$ & 7 & $29,943 \pm 3264$ & 97.26 & 2.74 & & 130 \\
\hline $\begin{array}{l}\text { D. acuminata + Danish } \\
\text { M. rubrum }\end{array}$ & 7 & $115,470 \pm 9490$ & 99.40 & 0.60 & & 90 \\
\hline $\begin{array}{c}\text { D. acuminata }+ \\
\text { Spanish M. rubrum }\end{array}$ & 7 & $58,413 \pm 3134$ & 86.62 & 10.38 & & 130 \\
\hline $\begin{array}{l}\text { D. acuta + Danish } \\
\text { M. rubrum }\end{array}$ & 15 & $21,967 \pm 2627$ & 81.62 & 18.38 & & 100 \\
\hline $\begin{array}{l}\text { D. acuta }+ \text { Spanish } \\
\text { M. rubrum }\end{array}$ & 15 & $42,733 \pm 3225$ & 100 & & & 100 \\
\hline $\begin{array}{l}\text { D. acuminata + Danish } \\
\text { M. rubrum }\end{array}$ & 15 & $225,800 \pm 9616$ & 100 & & & 100 \\
\hline $\begin{array}{c}\text { D. acuminata }+ \\
\text { Spanish M. rubrum }\end{array}$ & 15 & $58,900 \pm 265$ & 100 & & & 100 \\
\hline
\end{tabular}




\subsection{Quantitative Toxin Analysis Using Low Resolution Mass Spectrometry}

Dinophysis acuminata and D. acuta showed different toxin profiles. In both experiments, D. acuta produced OA, DTX2, and PTX2, whereas D. acuminata produced only OA (Table 2). Supernatants were not analyzed in this study and PTX2 derivatives could not be studied due to toxin degradation during the hydrolysis procedure [46]. Toxin quantification, pre- and post-hydrolysis, was used to indicate the potential presence of esters of the OA-group toxins in the samples from the two experiments.

During mid-exponential phase in Experiment 1, hydrolyzed samples of D. acuminata had 1.6 times more OA per cell than the non-hydrolyzed ones. Dinophysis acuminata contained 2.4 times more free OA (22 $\left.\mathrm{pg} \mathrm{cell}^{-1}\right)$ and three-fold more total OA ( $35 \mathrm{pg}$ cell $\left.^{-1}\right)$ than D. acuta, the latter, however, contained a significant cell quota of PTX2. Results of a one-way analysis of variance (ANOVA) when comparing both triplicates were statistically significant $(\mathrm{F}(9.96)>7.71 ; p<0.05)$. In the case of $D$. acuta, total OA was 33\% higher than free OA, whereas the amounts of DTX2 were nearly the same.

Estimated biovolumes of the different species were $65 \mu^{3}$ for Teleaulax amphioxeia, $2169 \mu^{3}$ and $2900 \mu \mathrm{m}^{3}$ for the Spanish and Danish Mesodinium, respectively, and 16,752 $\mu \mathrm{m}^{3}$ and 54,333 $\mu \mathrm{m}^{3}$ for D. acuminata and D. acuta respectively. Thus, the Danish Mesodinium was approximately $33 \%$ larger than the Spanish one, and D. acuta approximately three times larger than D. acuminata.

During the first phase of Experiment 2, D. acuta contained more OA per cell than D. acuminata. During the second phase of the experiment, cells from prey-limited cultures of D. acuta had more OA and DTX2 per cell than the well-fed cells and the same pattern was found for OA in D. acuminata cultures. Toxin per cell values under both nutritional conditions was compared.

ANOVA results were significant for OA in D. acuta fed Spanish M. rubrum $(\mathrm{F}(20.99)>10.13$; $p<0.05)$ and D. acuminata fed both strains of M. rubrum, $(\mathrm{F}(11.02)>10.13 ; p<0.05)$ with the Spanish and $(\mathrm{F}(16.70)>7.71$; and, $p<0.05)$ with the Danish M. rubrum. For DTX2 and PTX2, ANOVA results were significant only in the case of $D$. acuta fed Spanish M. rubrum, these results being (F (12.91) $>10.13 ; p<0.05)$ for DTX2 and (F (13.38)>10.13; $p<0.05)$ for PTX2. Total OA content per cell in prey-limited D. acuminata cultures (close to stationary phase) were on average 3.6 (Danish Mesodinium) and 3.5 times (Spanish Mesodinium) higher than well-fed cells (closer to exponential growth phase). In fact, ANOVA results were only significant for OA in these two cases, being $(\mathrm{F}(55.53)>10.13 ; p<0.05)$ and $(\mathrm{F}(59.59)>7.71 ; p<0.05)$ for the Spanish and Danish M. rubrum feeding, respectively. In the case of total and free DTX2 in D. acuta, again results were significant only with D. acuta fed Spanish M. rubrum (F (17.13)>10.13; $p<0.05)$. When comparing hydrolyzed and non-hydrolyzed samples, ANOVA analysis was significant only for D. acuta well-fed with Spanish M. rubrum. 
Table 2. Toxin cell contents per biovolume and per cell (average \pm standard deviation, $n=3$ ) of D. acuminata and D. acuta cells from the baseline experiment (Experiment 1, mid-exponential growth phase) and from cultures under different nutritional status and prey (Experiment 2). Abbreviations: Sp $=$ Species, PO = Prey origin, GP = Growth Phase, NS = Nutritional Status, ME = mid-exponential, ES = Spain, DK = Denmark.

\begin{tabular}{|c|c|c|c|c|c|c|c|c|c|c|c|c|}
\hline \multirow[t]{3}{*}{$\mathrm{Sp}$} & \multirow[t]{3}{*}{ PO } & \multirow[t]{3}{*}{ GP/NS } & \multicolumn{10}{|c|}{$\begin{array}{c}\text { Toxin Contents } \\
\mathrm{pb}=\text { per Biomass }\left(\mathrm{fg} \mu \mathrm{m}^{-3}\right), \mathrm{pc}=\text { per Cell }(\mathrm{pg} \text { cell } \\
\end{array}$} \\
\hline & & & \multicolumn{2}{|c|}{ Free OA } & \multicolumn{2}{|c|}{ Total OA } & \multicolumn{2}{|c|}{ Free DTX2 } & \multicolumn{2}{|c|}{ Total DTX2 } & \multicolumn{2}{|c|}{ PTX2 } \\
\hline & & & $\mathrm{pb}$ & pc & $\mathrm{pb}$ & pc & $\mathrm{pb}$ & pc & $\mathrm{pb}$ & pc & $\mathrm{pb}$ & pc \\
\hline D. acuta & ES & $\mathrm{ME}$ & $0.17 \pm 0.03$ & $9.2 \pm 2.0$ & $0.22 \pm 0.03$ & $12.2 \pm 2.3$ & $0.07 \pm 0.01$ & $3.8 \pm 0.6$ & $0.08 \pm 0.01$ & $4.4 \pm 0.9$ & $0.41 \pm 0.14$ & $22.2 \pm 9.4$ \\
\hline D. acuminata & ES & ME & $1.05 \pm 0.34$ & $21.5 \pm 0.5$ & $2.1 \pm 0.3$ & $35.2 \pm 6.8$ & & & & & & \\
\hline \multirow{2}{*}{ D. acuta } & ES & $\begin{array}{l}\text { Well-Fed } \\
\text { Prey-limited }\end{array}$ & $\begin{array}{l}0.55 \pm 0.06 \\
1.49 \pm 0.24\end{array}$ & $\begin{array}{c}30.0 \pm 3.7 \\
76.7 \pm 18.6\end{array}$ & $\begin{array}{l}0.75 \pm 0.07 \\
1.36 \pm 0.11\end{array}$ & $\begin{array}{l}41.0 \pm 4.9 \\
74.1 \pm 8.2\end{array}$ & $\begin{array}{l}0.24 \pm 0.03 \\
0.56 \pm 0.11\end{array}$ & $\begin{array}{l}13.5 \pm 1.7 \\
30.2 \pm 8.5\end{array}$ & $\begin{array}{l}0.32 \pm 0.06 \\
0.60 \pm 0.05\end{array}$ & $\begin{array}{l}17.4 \pm 4.1 \\
32.4 \pm 3.8\end{array}$ & $\begin{array}{l}0.69 \pm 0.12 \\
1.29 \pm 0.15\end{array}$ & $\begin{array}{c}38.0 \pm 8.2 \\
59.3 \pm 11.8\end{array}$ \\
\hline & DK & $\begin{array}{l}\text { Well-Fed } \\
\text { Prey-limited }\end{array}$ & $\begin{array}{l}0.53 \pm 0.12 \\
0.64 \pm 0.08\end{array}$ & $\begin{array}{l}28.7 \pm 8.1 \\
34.6 \pm 5.4\end{array}$ & $\begin{array}{l}0.66 \pm 0.11 \\
0.71 \pm 0.07\end{array}$ & $\begin{array}{l}35.9 \pm 7.07 \\
38.6 \pm 4.5\end{array}$ & $\begin{array}{l}0.26 \pm 0.03 \\
0.32 \pm 0.04\end{array}$ & $\begin{array}{l}14.2 \pm 2.2 \\
17.4 \pm 2.7\end{array}$ & $\begin{array}{l}0.30 \pm 0.01 \\
0.35 \pm 0.03\end{array}$ & $\begin{array}{l}16.5 \pm 0.8 \\
19.0 \pm 2.3\end{array}$ & $\begin{array}{c}0.78 \pm 0.01 \\
0.8 \pm 0.09\end{array}$ & $\begin{array}{l}70.0 \pm 0.8 \\
43.6 \pm 6.2\end{array}$ \\
\hline \multirow{2}{*}{ D. acuminata } & ES & $\begin{array}{c}\text { Well-Fed } \\
\text { Prey-limited }\end{array}$ & $\begin{array}{l}0.37 \pm 0.14 \\
1.02 \pm 0.20\end{array}$ & $\begin{array}{c}6.0 \pm 3.0 \\
17.1 \pm 4.6\end{array}$ & $\begin{array}{l}0.36 \pm 0.13 \\
1.28 \pm 0.03\end{array}$ & $\begin{array}{c}6.0 \pm 2.8 \\
21.5 \pm 0.7\end{array}$ & & & & & & \\
\hline & DK & $\begin{array}{c}\text { Well-Fed } \\
\text { Prey-limited }\end{array}$ & $\begin{array}{l}0.49 \pm 0.09 \\
1.44 \pm 0.32\end{array}$ & $\begin{array}{c}8.3 \pm 1.5 \\
24.0 \pm 6.5\end{array}$ & $\begin{array}{l}0.59 \pm 0.08 \\
1.93 \pm 0.23\end{array}$ & $\begin{array}{c}9.8 \pm 1.7 \\
32.3 \pm 4.7\end{array}$ & & & & & & \\
\hline
\end{tabular}




\section{Esters of OA-Group Toxins}

The quantitative analysis using low resolution mass spectrometry suggested a large difference between total and free OA in D. acuta well-fed with Spanish Mesodinium. Indeed, spectra that were acquired from targeted high-resolution tandem mass spectrometry in both positive and negative ionization modes strongly suggested the presence of an OA ester, which had not been previously described in D. acuta [47].

\subsection{Data Treatment for Non-Targeted Liquid Chromatography High Resolution Mass Spectrometry}

Three variables were considered in the data analysis: (i) "species" (D. acuta, D. acuminata, M. rubrum and T. amphioxeia); (ii) "prey origin" (Danish and Spanish M. rubrum strain) and (iii) "nutritional status" (well-fed and prey-limited). Variable "species" was used in Experiment 1 to separate the response of different organisms in the principal component analysis (PCA): The X-axis explained the highest variability, i.e., $45.66 \%$ in $\mathrm{ESI}^{+}$mode (data not shown) and $57.08 \%$ in $\mathrm{ESI}^{-}$mode (Figure 3).

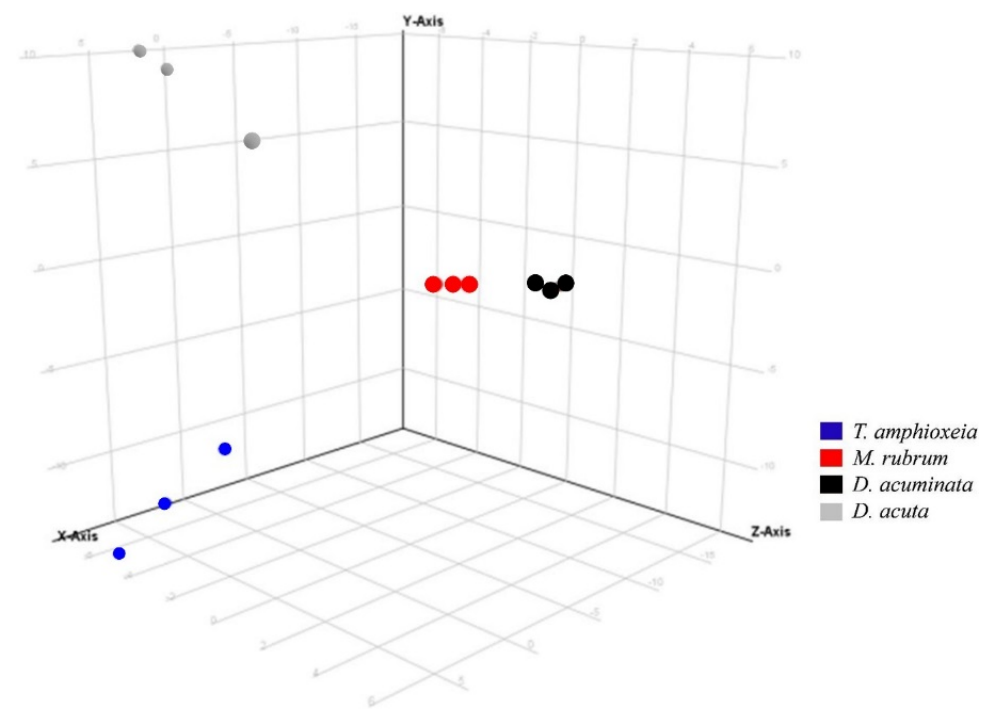

Figure 3. Principal component analysis of features detected in negative ionization mode according to the variable "species" in Experiment 1. First, second and third principal components (PC1, PC2, and PC3, the three components representing the largest fraction of the overall variability) are displayed on the $X, Y$, and Z-axis. Variability explained by each component: PC1 (X-axis) 57.1\%, PC2 ( $Y$-axis) $26.5 \%$, PC3 (Z-axis) $11.1 \%$ (total 94.7\%). Nota bene: biological replicates of each species group together, indicating the consistent differences in chemical profiles of each species.

A similar response was observed using the same variable in Experiment 2 (Figure 4). Species separation was clearly visible, with replicates of Mesodinium, Teleaulax, and the two species of Dinophysis forming separate clusters in principal component analysis. Intraspecific differences in each of the two Dinophysis species were larger than in Experiment 1, most likely due to the increased complexity of Experiment 2 since this one included treatments with different prey origins and nutritional status.

When Teleaulax and Mesodinium were excluded from the dataset, D. acuminata and D. acuta were clearly separated by the variable "species" (Figure 5A), also showing the highest number of species-specific compounds ( $p<0.001$; see Tables S3A-C and S4A-C for compounds specific to both Dinophysis species ranked by increasing $p$-values). This example also highlights the meaning of each principal component, as component 1 (Figure 5A) corresponds to the separation according to species, whereas component 2 corresponds to grouping according to prey origin. As component 2 explains less than half of the variability as compared to component 1 , the variable "species" can be considered most important, followed by prey origin. 


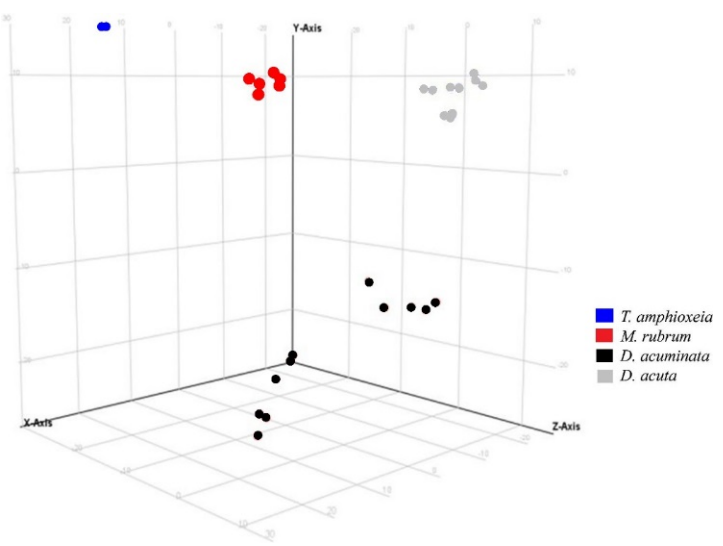

Figure 4. Principal component analysis of features detected in negative ionization mode according to the variable "species" in Experiment 2. First, second and third principal components (PC1, PC2, and PC3, the three components representing the largest fraction of the overall variability) are displayed on the $X, Y$, and Z-axis. Variability explained by each component: PC1 ( $X$-axis) 45.4\%, PC2 ( $Y$-axis) $21.9 \%$, PC3 (Z-axis) $15.0 \%$ (total $82.3 \%$ ). Nota bene: biological replicates of each species group together, albeit somewhat less than in Experiment 1 (Figure 3) due to the increased complexity of Experiment 2 (additional Danish Mesodinium and different nutritional status).

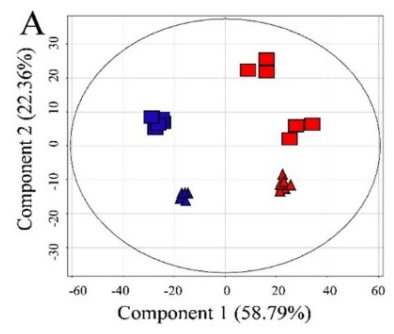

B

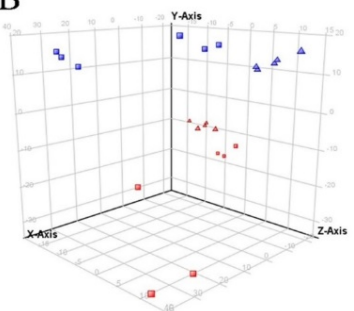

C

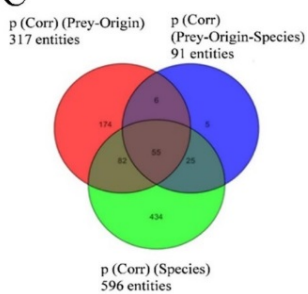

Figure 5. (A) Principal component analysis of features detected in the two Dinophysis species (excluding prey species) in negative ionization mode showing variables "species" and "prey origin" in Experiment 2. First and second principal components (the two components representing the largest fraction of the overall variability) are displayed on the $X$ and $Y$-axis. Variability explained by each component: component 1 (X-axis 58.8\%), component 2 ( $Y$-axis) $22.4 \%$ (total 81.2\%). Dinophysis acuminata and D. acuta ("species") are represented in red and blue color, respectively and the origin of Mesodinium used as prey are represented as triangles and rectangles for Denmark and Spain, respectively; (B) Principal component analysis of features detected in positive ionization mode in Experiment 2 (grouping by species and prey origin). First, second and third principal components (PC1, PC2, and PC3, the three components representing the largest fraction of the overall variability) are displayed on the $X, Y$, and $Z$-axis Variability explained by each component: PC1 (X-axis) 37.7\%, PC2 (Y-axis) 26.7\%, PC3 (Z-axis) 9.9\% (total 74.3\%). Nota bene: D. acuta samples in top half of the graph and $D$. acuminata samples in the bottom half of the graph, i.e., separation by species driven by the second component ( $Y$-axis). "Species" and "prey origin" are represented in the figure as for $\mathrm{A} ;(\mathbf{C})$ Venn diagram explaining overlap of features specific to species, prey-origin, and interactions of these parameters (see also Supplementary Table S4A-C). 
In the case of $D$. acuminata, many compounds (107) were specific to one of the two nutritional conditions (Figure 6). Still, taking the previous observations into account, only metabolites appearing under "species" and "prey origin" variables were considered in the following sections.

While the above analyses did not investigate the nature of the features that were detected in the non-targeted HRMS analysis, the following sections give an overview of the tentative identifications after comparisons with the databases METLIN and/or Marine Natural Products Dictionary.

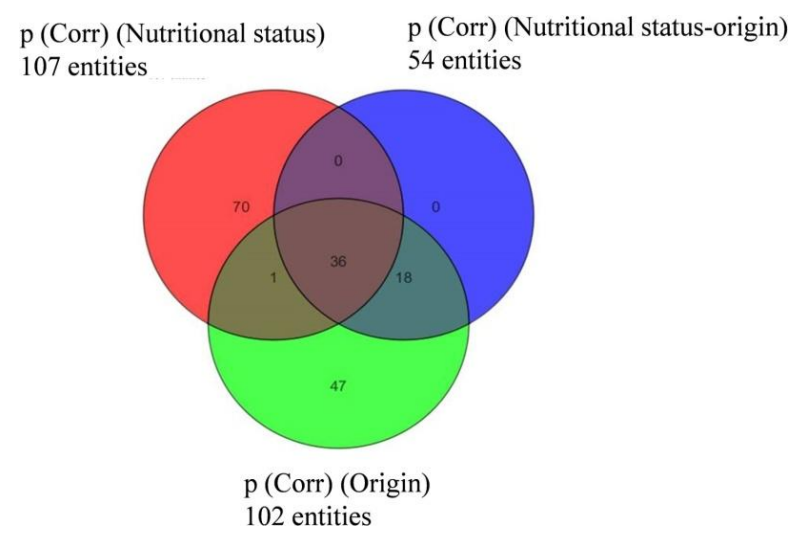

Figure 6. Venn diagram indicating the distribution of compounds specific to or common within groups of Dinophysis acuminata depending on "prey origin" and "nutritional status" from Experiment $2\left(\mathrm{ESI}^{-}\right)$.

\subsubsection{Compounds with an Already Known Physiological Meaning}

Common to All Species

Dinophysis cells that were harvested from Experiment 1 had been previously washed to eliminate the remains of cryptophytes and M. rubrum from the cultures, but this step was not repeated for Experiment 2. For this reason, only compounds appearing in both experiments are shown in Table S1A,B.

Within the compounds common to all species, the one with the highest score was a molecule (Compound ID: S1A-3) which showed the maximal relative abundance in T. amphioxeia, decreasing progressively from M. rubrum to Dinophysis. When considering the normalized abundance of this compound in both experiments, its transfer through the food chain from T. amphioxeia to Dinophysis is plausible. This compound was previously found in the marine dinoflagellate Heterocapsa circularisquama and at a concentration $\geq 0.5 \mu \mathrm{g} \mathrm{mL}-1$ it showed cytolytic activity toward oyster heart cells [48]. Another compound common to all species in both experiments was a galacto-glycerolipid-like compound (Compound ID: S1A-2 and S1B-8), in particular, a mono-galactosyl-diacyl-glycerol (MGDG 18:5), which had large quantities of polyunsaturated fatty acids. Mono- and di-galactosyl-diacylglycerols (MGDGs/DGDGs) are present in cyanobacteria and chloroplasts, and are used to preserve the Photosystem II (PSII) components. In higher plants, changes in the mono- and di-galactosyl-diacylglycerol ratios (MGDG/DGDG) are related to environmental changes that are affecting the structure of thylakoid membranes [49]. In fact, MGDGs with different structures (MGDG 20:5/16:3) appeared in Experiment 2 (Compounds ID: S1B-6, S1B-10, and S1B-11). All three compounds had the highest content in T. amphioxeia, and this relative content decreased from Mesodinium to Dinophysis (particularly in the case of D. acuta). Different structures of these lipids (MGDG and DGDG) have been suggested to be responses to changes in temperature [50]. Such responses were observed in different strains of Pyrocystis lunula, P. noctiluca, and P. fusiformis, in which DGDG (20:5/18:4) and DGDG (20:5/18:5) were the dominant galactolipids in all the strains at temperatures of $25^{\circ} \mathrm{C}$ and $15^{\circ} \mathrm{C}$, respectively, whereas MGMG (20:5/18:5) was predominant at $15{ }^{\circ} \mathrm{C}$.

In our study, the presence of glycerolipids was generally reduced under prey-limited conditions, but these lipids did not seem to be specific to either D. acuminata or D. acuta. 
Compound ID: S1B-4, which was a minor compound in both species of Dinophysis fed Danish M. rubrum (also present in all the species), was identified as a phosphatidyl glycerol (PG)-like molecule (through the METLIN database albeit with a low score of 53.04\%). This phospholipid is an important component of thylakoid membranes [51], and its absence produces photosynthesis photo-inhibition [52]. After the description of the two previous compounds, it is worth mentioning that from algae to higher plants, P-limitation leads to an increased galactoglycerolipid/phosphoglycerolipid ratio [53,54]. However, the same compound was also identified as the methylester of melanodocin, an isomer of acanthifolicin (Marine Natural Products Dictionary, score of 99.3\%). Acanthifolicin is a sulphide of okadaic acid, and this compound had not been reported from dinoflagellates but had been initially isolated from the sponge Halichondria melanodocia. However, the presence of this compound in all species, including Teleaulax amphioxeia, supports the hypothesis of a (PG)-like molecule. In any case, further studies are necessary to confirm the compound identity and gain new insights into its role.

Compounds Exclusive to the Ciliate Mesodinium

No compounds that were specific to the M. rubrum strains were found. This result may well be related to some residual contamination from T. amphioxeia in ciliate cultures, but also to the fact that Mesodinium keeps the full set of cryptophyte organelles (nucleus, mitochondria, chloroplast) and the cryptophyte transcriptional machinery active after sequestration [26,55].

\section{Compounds Exclusive to Teleaulax amphioxeia}

Two compounds that were specific to the cryptophyte T. amphioxeia (Table S2, compounds ID: S2-1 and S2-2) were found. One of them (Compound ID: S2-2) matched the group of phospholipids, which form part of eukaryotic cell membranes with the suggested function of maintaining their fluidity [56].

Compounds Exclusive to One of the Two Species of Dinophysis

A glycerol-like compound (Compound ID: S7A-1) was identified only in D. acuminata from Experiment 2 (Table S7A). This compound is required for the synthesis of triacylglycerols, phospholipids, and glycolipids. Amongst glycolipids, glycosphingolipids act as cell adhesion mediators and signal transduction modulators. When they are associated with other proteins (glycosynapse), they act as functional groups through which glycosylation-dependent cell adhesion coupled with signal transduction takes place [57]. These glycosphingolipids, together with other polysaccharides, are involved in membrane formation and were found to be overexpressed during bloom conditions in field populations of Levanderina fissa [58]. Stigmastane-like compounds (Compounds ID: S10-3 and S10-4) were only present in well-fed cells of D. acuminata (fed Danish M. rubrum; Table S10). The cellular content of this kind of sterols was found to increase in Gymnodinium sp. cultures when they reached the stationary phase [59]. Maximum levels of other sterol lipids, e.g., compounds ID: S11B-1 and S11B-4, were found in starved cells of D. acuminata (Danish M. rubrum) (Table S11B).

Protochlorophyllide (Compound ID: S11B-9), which is an ester-like molecule that is involved in the biochemical route for the synthesis of chlorophyll compounds [60], was only found in prey-limited cells of $D$. acuminata initially fed Danish M. rubrum (Table S11B), together with a phaeophytin a-like compound (Compound ID: S11B-5; chlorophyll a degradation product).

\subsubsection{Compounds First Found in Other Marine/Terrestrial Organisms}

Many of the compounds that were found in either or both Dinophysis species were tentatively identified as polyketides. Polyketides are a structurally diverse group that is constituted by a carbon chain synthesized by a family of enzymes called polyketide synthases (PKSs). Genes coding for PKSswere first cloned and sequenced in bacteria and fungi, and later identified and associated with the dinoflagellate Karenia brevis by Snyder et al. [61,62]. 


\section{Compounds Present in Both Species}

Several compounds that were identified in both species of Dinophysis from Experiment 2 (Table S5A,B) were tentatively identified as having first been found in marine invertebrates (corals and sponges). For example, the lipophilic toxin OA (Compound ID: S5A-1) was first isolated from the sponges Halichondria okadai and H. melanodocia [36]; 5,8-epidioxysterols (Compound ID: S5A-3) were isolated from corals (Sinularia flexibilis, [63]), which may feed on toxigenic dinoflagellates [64].

Compounds Exclusive to One of the Two Species of Dinophysis

\section{Dinophysis acuminata}

Several compounds previously isolated from sponges were tentatively identified in D. acuminata (Table S7B, Compound ID: S7B-1), but were not related with a particular "prey-origin" nor "nutritional-status" condition. Other compounds that were first isolated also in sponges and skates (genus Raja) were identified in well-fed cells of this species (Compound ID: S10-5), regardless of the Mesodinium strain that was used as prey (Table S10). Different alkaloid-like compounds previously found in starfish and sponges were found in food-limited D. acuminata cells (Table S11A,B, compound ID: S11B-11).

\section{Dinophysis acuta}

Brevetoxins and OA-related toxins may be classed as polyketides [65]. While OA was present in both $D$. acuta and D. acuminata, a peak of an isomer appeared just a few seconds after OA in D. acuta only, which corresponded to dinophysistoxin-2 (DTX2). Dinophysistoxin 1 (DTX1) and DTX2 often co-occur with OA, but the two DTXs rarely co-occur. This is probably due to the fact that DTX2 has a stereochemistry opposite to that of DTX1 at their C-35 [66], which suggests a significant difference in the biosynthetic pathway.

In agreement with results from targeted analysis by low resolution mass spectrometry (Table 2), PTX2 was also specific to D. acuta in the non-targeted analysis (Table S6B, compound ID: S6B-5). The abundance of PTX2 was slightly higher in prey-limited than in well-fed cells, in particular, for the cells that were fed Spanish M. rubrum.

A compound (Compound ID: S9A-4) that was tentatively identified as Prorocentin was the most abundant of all the compounds specific to prey-limited D. acuta fed Danish M. rubrum. Prorocentin, which was first isolated from the toxic dinoflagellate Prorocentrum lima [67], is a polyketide suggested to share a biosynthethic pathway with OA.

Putative compounds that are found only in D. acuta (i.e., Compound IDs: S6B-2 and S6B-9) were described in the sponge Sigmosceptrella [68], and were later found in other marine organisms, such as the coral Klyxum flaccidum ([69], Table S6A,B).

A compound originally described in sharks (Compound ID: S8-1) was found in well-fed (Danish M. rubrum) cells of D. acuta (Table S8). However, when food was limiting, a putative anti-feedant compound (Compound ID: S9A-1) that was initially isolated from the cyanobacteria Lyngbya majuscula [70], was identified together with other compounds firstly identified in sponges, molluscs, and bacteria (Table S9A,B).

\section{Discussion}

\subsection{Growth Curves}

Growth rates that were obtained in Experiment 2 for both Dinophysis species demonstrated the significant effect of prey source (Spanish or Danish M. rubrum strain). Interestingly, D. acuminata showed the highest growth rates under both nutritional conditions when it was initially fed Danish $M$. rubrum. Only $0.03 \%$ of genetic dissimilarity was observed when comparing both Mesodinium strains, but the biovolume of the Danish strain was 33\% larger than that of the Spanish one. In this regard, it 
is well known that prey size and morphological features affect the selectivity of predators towards specific prey organisms. This phenomenon has previously been demonstrated for the heterotrophic dinoflagellates Oxyrrhis marina, Protoperidinium pallidum, and P. steinii: when they were fed algae with different sizes, their growth was mainly supported by the larger-sized specimens [71,72].

\subsection{Toxin Quota and Target Analysis}

Toxin content per cell of all toxins was higher in Dinophysis cultures during the prey-limited phase (Experiment 2), except for PTX2 in D. acuta fed Danish ciliate, which was probably related to the poor physiological state of that culture (Table 2). Earlier experiments with D. acuminata [73] with D. fortii [74] showed that prey limitation reduced its growth and increased toxin content per cell due to an imbalance between cell division and toxin production rates. The different results that were observed for $D$. acuta are in accordance with the observations on its feeding behavior: D. acuta did not feed well on the Danish ciliate, a fact that would also explain the lack of differences between well-fed and prey limited phases (Table 2, Experiment 2). In contrast, D. acuta reached the highest content of OA per cell when feeding on Spanish Mesodinium (Table 2, Experiment 2).

Toxin content per cell observed in both Dinophysis species during Experiments 1 and 2 (D. acuta: 70 pg PTX2 and 75 pg OA cell ${ }^{-1}$; D. acuminata: 32 pg OA cell $^{-1}$ in hydrolyzed samples) was significantly higher than any ever-recorded in picked cells of $D$. acuminata and D. acuta strains from the Galician Rías. Earlier studies on Dinophysis strains from this region showed maximum values of 9.4, 6.6 and $6.1 \mathrm{pg}$ cell $^{-1}$ of OA, DTX2, and PTX2, respectively [75], and a simpler profile with only PTX2 (32.3 pg PTX2 cell ${ }^{-1}$ ) in D. acuta from another year [76].

Toxin analysis that was carried out during the baseline experiment (Experiment 1 ) showed the same toxins as in Experiment 2, but their proportions were somewhat different and the cell-toxin quota was lower in Experiment 1. Thus, PTX2 and total DTX2 toxin content in D. acuta was only 22 and 4 pg cell $^{-1}$, respectively, in Experiment 1, while the largest amount of these toxins were 70 and $30 \mathrm{pg} \mathrm{cell}^{-1}$, respectively, during parts 1 and 2 of Experiment 2. During Experiment 1, OA in D. acuminata reached the highest content per cell $\left(\sim 21.5 \mathrm{pg} \mathrm{OA} \mathrm{cell}^{-1}\right)$, similar to those that were acquired during Experiment 2. Contrarily, inExperiment 2, it was D. acuta that reached the highest content of OA per cell $\left(\sim 76 \mathrm{pg}\right.$ OA cell $\left.{ }^{-1}\right)$, while during Experiment 1 OA toxin content per cell was found in a minor quantity $\left(\sim 9\right.$ pg OA cell $\left.{ }^{-1}\right)$. The time lag between Experiments 1 and 2 was approximately three months, so it is unlikely that toxin loss occurred in D. acuminata cultures, as has been observed with other dinoflagellate cultures. As an example, the losses of toxin content in a strain of Alexandrium lusitanicum ( $=$ A. minutum) have been related to slower growth in the laboratory [77].

\subsection{Semi-Quantitative Non-Targeted Analysis: Comparison of Larger Parts of Metabolomes}

A multivariate analysis was used to estimate differences between phenotypes, at the chemical level, in relation to three variables: "species", "prey origin", and "nutritional status". The variable "species" led to the highest separation within samples, followed by "prey origin". The "nutritional status" did not provide clear-cut results in the case of $D$. acuta, neither during the growth experiments nor in the PCA analysis. In contrast, in the case of D. acuminata, distinct results were obtained depending on the "nutritional status". Statistical analysis that was carried out here gave enough separation between the organisms, however future studies should include partial least square-discriminant (PLS-DA) analysis and Variable Importance in Projection VIP score plot, in addition to PCA to underscore such separation.

Only a few lipid-derivatives could be tentatively identified in every species in the present study and were likely transferred through the three-species food chain (Teleaulax-Mesodinium-Dinophysis). Metabolomic studies aim to unveil a comprehensive view of the metabolome, i.e., the set of metabolites a biological entity may produce, although datasets in this field can be convoluted [78]. This part of the study would fit in the field of partial ecometabolomic studies (PEM), a term coined by Sardans et al. [79], which encompasses ecophysiological metabolomic studies focused on the identification of metabolites that are produced in response to specific biotic/abiotic effects on organisms. Formally speaking about 
metabolomics, intra- and extracellular metabolites should be analyzed [80]. The main objective of this work was to identify intracellular compounds (whether by formulae or by name) that were (i) common to all the species that were used in this study (T. amphioxeia, M. rubrum, Dinophysis species); (ii) specific to some of them; or, (iii) species-specific. It was not intended to be a comparison between both batches of samples (Experiments 1 and 2) as these types of analysis are "snapshots" of the cell at the time of being harvested, and they were, indeed, harvested at different times. Due to the diversity of the metabolome, it is not possible to identify all metabolite types [33]. This study represents a first application of these next-generation technologies to Dinophysis, and should be useful, among others, to identify molecular markers that are involved in predator-prey recognition and/or Dinophysis identification.

Regarding biological results, maximum yields were obtained in the D. acuminata strain fed Danish M. rubrum. Contrary effects were seen when the population of $D$. acuta, feeding on the same prey, declined during the second part of Experiment 2. Therefore, important questions regarding Experiment 2 were: could such compounds be involved in predator-prey recognition? If so, do these compounds belong to the Danish M. rubrum or are specific for D. acuminata or D. acuta?

Different alkaloids and lipids were mainly identified in prey-limited cells of $D$. acuminata that were initially fed Danish M. rubrum. In the case of D. acuta, the putative characterization of a compound with anti-feeding properties (Compound ID: S9A-1) could be associated with the shift to early stationary and senescent phases in this species. In fact, the release of secondary metabolites by dinoflagellates, and their effects have gained much attention during the last years. The term "allelopathy" can be understood as an adaptation [81] related to the secretion of secondary metabolites and other biochemicals [82]. Particularly, the lipopeptide Malyngamide A was shown to have anti-feeding properties that deterred the uptake by two species of coral red fishes of artificial food (mixture of water, agar, and powdered green alga) containing the lipopeptide [83]. Many identified features were first isolated in higher marine organisms implying roles in various ecological relationships. Okadaic acid was first isolated from the sponges Halichondria okadai and H. melanodocia [36], so it could well be that compounds found in other marine organisms in fact were derived from smaller-sized cells. Toxins from certain strains of the dinoflagellate Karlodinium veneficum displayed anti-feeding properties against the copepod Acantia atonsa [84]. In this context, Denticulatin A, which has been tentatively identified in both Dinophysis species (Compound ID: S4A-38), can be mentioned as a possible ichtyotoxic agent due to its polypropionate character.

Regarding the issue of how Dinophysis can recognize the ciliate M. rubrum as a prey, different glycolipids (e.g., Glycerol 1, 2-dialkanoates in D. acuminata) and other compounds identified only tentatively by their formulae were found. Raho et al. [13] used different lectin markers to detect the presence of cell-surface binding carbohydrates in Galician strains of D. acuminata and D. acuta. Such lectin markers showed positive results in both Dinophysis as well as in M. rubrum cells, suggesting that lectins could play a key role in predator-prey recognition. Wood-Charlson et al. [85] showed that the cell surface of Symbiodinium contained glycan ligands ( $\alpha$-Mannose/ $\alpha$-Glucose and $\alpha$-Galactose residues), which bound with two different lectins (ConA and Jac) that were found in Fungia scutaria coral larvae, meaning that some recognition mechanism is playing an important role in the coral/dinoflagellate symbiosis. Several recent studies pointed out the excretion by Dinophysis of a mucus trap to catch its prey [86-88]. Mafra et al. [86] demonstrated that the "toxic substance" in the mucus was not a lipophilic toxin. These authors suggested that excreted toxic substances, together with the mucus, were part of Dinophysis feeding strategies; however, prey capture by Dinophysis using a mucus trap was not observed in the present study. Finally, we repeat that all the identifications in this study must be considered as tentative, since no reference compounds are available for many natural products, and full scan high resolution mass spectrometry only allows for an initial comparison with existing databases, but without complete structural confirmation. Further studies need to be carried out to follow up on these results and confirm the actual identity of the metabolites. 


\section{Material and Methods}

\subsection{Cultures}

Dinophysis acuminata (strain VGO1349) was isolated from Ría de Vigo in July 2016 and Dinophysis acuta (VGO1065) from Ría de Pontevedra in October 2010. A strain of the ciliate Mesodinium rubrum (AND-A0711, Acc. Number KP142651) and the cryptophyte Teleaulax amphioxeia (AND-A0710; Acc. Number KP142646) were isolated from Huelva, Southwest Spain, in 2007. Cultures of M. rubrum, fed the cryptophyte T. amphioxeia, were periodically given to Dinophysis as prey. An additional strain of M. rubrum (MrDK-2009, Acc. Number MG018339), which was isolated from Helsingør Harbor (Denmark) during summer 2009, was used in this study. Images of these organisms are shown in Figure 7.

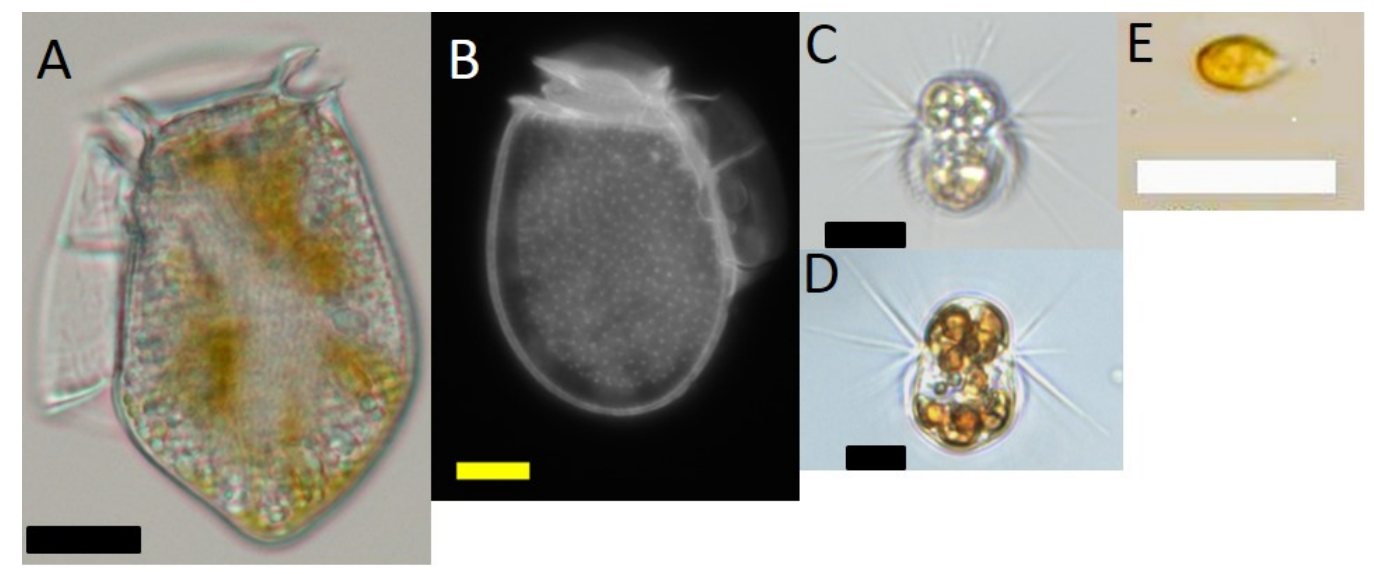

Figure 7. Light microscope micrographs of (A) Dinophysis acuta;(B) D. acuminata; (C) Mesodinium rubrum from Spain; (D) M. rubrum from Denmark; (E) Teleaulax amphioxeia. Scale bars: (A) (20 $\mu \mathrm{m})$; and, (B-E) $(10 \mu \mathrm{m})$.

\subsection{DNA Extraction, Polymerase Chain Reaction (PCR), 185 Sequencing and Phylogenetic Analysis of Mesodinium}

A culture of M. rubrum (Mr-DK2009) fed the cryptophyte Teleaulax acuta was starved for two weeks until no prey could be detected. Single cells were picked and transferred to $0.2 \mathrm{~mL}$ PCR tubes containing $100 \mu \mathrm{L}$ of milli-Q water and 10\% ( $w / v)$ Chelex 100 (Sigma-Aldrich \#C7901, St. Louis, MO, USA). For DNA extraction, the PCR tubes were vortexed for $5 \mathrm{~s}$, spun down in a microcentrifuge for $10 \mathrm{~s}$, and subsequently incubated at $95^{\circ} \mathrm{C}$ for $20 \mathrm{~min}$ [89]. After incubation, the tubes were centrifuged again for $10 \mathrm{~s}$ and stored at $4{ }^{\circ} \mathrm{C}$ until use for PCR reactions.

DNA extract $(2 \mu \mathrm{L})$ was used as template in the subsequent PCR reactions. The following primer pairs were used: 4617F-Meso580R; Meso245-UNIDEUK1416R; Meso580F-Meso1480R; Meso1200F-Meso28S_R; and, ITS1-Dir-2CR (see Table 3). PCR reactions were carried out in $25 \mu \mathrm{L}$ reaction-tubes containing, $1.5 \mathrm{mM} \mathrm{MgCl}_{2}, 0.8 \mathrm{mM}$ dNTPs (VWR \#733-1363), 0.5 units polymerase (VWR \#733-1301), $0.4 \mu \mathrm{M}$ primers using the following reaction settings: $2 \mathrm{~min}$ at $95^{\circ} \mathrm{C}$, followed by 40 cycles: $95^{\circ} \mathrm{C}$ for $30 \mathrm{~s} ; 57^{\circ} \mathrm{C}$ for $30 \mathrm{~s} ; 72{ }^{\circ} \mathrm{C}$ for $50 \mathrm{~s}$; and finally, 5 min at $72{ }^{\circ} \mathrm{C}$.

PCR products were tested on a $2 \%$ agarose gel and purified with a QIAquick PCR purification kit (Qiagen \#28106). Purified samples were sent to Macrogen (Macrogen Europe, Amsterdam, The Netherlands) for Sanger sequencing in both directions. Sequence analysis (trimming, assembly, BLAST) was done with Geneious version 10.1.3. For the phylogenetic analysis, additional sequences of the SSU rRNA gene were downloaded from GenBank and were aligned using T-Coffee, as implemented by intcoffe.crg.cat. The alignment included 2780 characters and was uploaded to the South of France bioinformatics platform for PhyML 3.0 analysis with Smart Model Selection (best model was GTR 
$+\mathrm{G}+\mathrm{I})$, using the Akaike Information Criterion and performing 1000 bootstrap replicates [90,91]. Bayesian Inference was performed with MrBayes 3.2.6 using a GTR + I + $\Gamma$ model, as implemented in Geneious $^{\circledR}$ 10.2.2 (Biomatters Ltd., Auckland, New Zealand) [92]. The following settings were used: four simultaneous Markov chain Monte Carlo (MCMC) run for 1,000,000 generations, sampling every 100 generations. The first $25 \%$ of trees were discarded as burn in. Finally, a neighbor-joining tree was build, using the Jukes-Cantor genetic distance model and 10,000 bootstrap replicates, as implemented in Geneious ${ }^{\circledR} 10.2 .2$.

Table 3. Sequences of primers used for the genetic analysis of Mesodinium.

\begin{tabular}{ccc}
\hline Name & ${\text { Sequence } \text { 5 }^{\prime} \mathbf{- 3}^{\prime}}^{\prime}$ & Reference $^{\prime}$ \\
4617F & TCCTGCCAGTAGTCATATGC & {$[93]$} \\
Meso580R & GACGTACAGACTACGGACG & {$[94]$} \\
Meso245F & CGACTCGACGTCCCG & {$[94]$} \\
UNIDEUK1416R & GTTTCAGACTTGTGTCCATACTA & {$[95]$} \\
Meso580F & CGTCCGTAGTCTGTACGTC & {$[94]$} \\
Meso1480R & CTAAACACTCGATCGGTAGG & {$[94]$} \\
Meso1200F & ATTCCGGTAACGAACGAGAC & {$[94]$} \\
Meso28S_R & AGACTTGGATGACTTTTATCACC & {$[94]$} \\
ITS1 & TCCGTAGGTGAACCTGCGG & {$[96]$} \\
Dir-2CR & CCTTGGTCCGTGTTTCAAGA & {$[97]$} \\
\hline
\end{tabular}

\subsection{Biovolume}

Measurements of the organisms that were studied (cryptophytes, Mesodinium, and Dinophysis) were carried out to estimate their biovolumes. These estimates were used to normalize data related to the identified features (for "feature" meaning explanation see below at Section 4.7.1). Imaging of 30 specimens of each Dinophysis species was carried out with an Axiocam HRC digital camera (Zeiss, Oberkochen, Germany) and measurements that were taken under a light microscope (Leica DMR, Germany) at $630 \mathrm{X}$ magnification. Dinophysis acuta geometric shape was considered equivalent to a cone plus a truncated cone and D. acuminata to a flattened ellipsoid. Biovolume estimates were based on the equations used in Olenina et al. [98]. Biovolumes of the two M. rubrum strains and T. amphioxeia were estimated with a particle counter (Multisizer 3 Coulter counter, Beckman, Roissy Charles De Gaulle, France) using triplicates of $10 \mathrm{~mL}$ for each species.

\subsection{Experiment 1 (Baseline Study)}

A preliminary experiment was carried out at IEO-Vigo to gain baseline information on the growth curves and metabolomes of the organisms. Triplicates of Dinophysis acuminata, D. acuta, M. rubrum, and T. amphioxeia where grown in $250 \mathrm{~mL}$ flasks filled with diluted (1:20) L1-Si medium [99] based on autoclaved seawater from Ría de Vigo with the salinity adjusted to 32 and a 12:12 h L:D cycle. Cultures were provided a light intensity of $\sim 250 \mu \mathrm{E} \mathrm{m}^{-2} \mathrm{~s}^{-1}$ and were kept in a temperature-controlled chamber at $15{ }^{\circ} \mathrm{C}$. Mesodinium rubrum was fed T. amphioxeia at a 1:1 ratio (Teleaulax:Mesodinium) and Dinophysis acuminata and D. acuta were fed the Spanish M. rubrum at a 10:1 ratio (Mesodinium:Dinophysis). More prey was added to Mesodinium when no cryptophytes were observed under the light microscope. To carry out toxin and non-targeted analyses, cultures that were harvested at mid-exponential phase were centrifuged at $3000 \times g$ for $20 \mathrm{~min}$ at $4{ }^{\circ} \mathrm{C}$, the supernatant removed and the pellets kept at $-80^{\circ} \mathrm{C}$ before being sent on dry ice to IFREMER-Nantes.

\subsection{Experiment 2 (Growth Curves)}

Experiment 2 was carried out at IFREMER-Nantes and was developed in two phases, the first one lasting 7 days and the second 15 days, under identical experimental conditions. For the first phase (7 days), Dinophysis species, the two strains of M. rubrum and T. amphioxeia were seeded in triplicate into seawater from the English Channel off St. Malo, enriched with diluted (1:20) L1-Si medium in 
$250 \mathrm{~mL}$ Erlenmeyer flasks ( $150 \mathrm{~mL}$ final volume), and kept in a culture room at $17^{\circ} \mathrm{C}$ with a $14: 10 \mathrm{~h}$ L:D cycle at $160 \mu \mathrm{E} \mathrm{m}^{-2} \mathrm{~s}^{-1}$. The two strains of M. rubrum were provided separately as prey for both Dinophysis species with a ratio 10:1 (M. rubrum:Dinophysis) on day 1. These were labeled as "well fed" treatments. The second phase (15 days) was carried out as previously described. The only difference was the longer duration of the second experiment (15 days), and that Dinophysis was fed only on day 0, and was therefore considered "prey-limited" at day 15 (starvation would have required being kept for weeks with no prey).

To estimate cell densities, samples of $10 \mathrm{~mL}$ (for Coulter counter) and $2 \mathrm{~mL}$ (sedimentation chambers) were taken every 2 days and were fixed with acidic Lugol's solution. Dinophysis cells were counted in sedimentation chambers under a Zeiss Invertoskop D microscope (Carl Zeiss AG, Oberkochen, Germany), Mesodinium with a Coulter counter, and T. amphioxeia, with a Nageotte hemocytometer counting chamber.

Specific growth rates $\left(\mu\right.$, day $\left.^{-1}\right)$ of Dinophysis species were calculated as:

$$
\mu=\ln \left(N_{t} / N_{o}\right) / t
$$

where $N_{o}$ was the initial and $N_{t}$ the final density of Dinophysis after time $t$.

\subsection{Toxin Analysis}

All the toxin analyses were performed at the Phycotoxins Laboratory (IFREMER-Nantes).

\subsubsection{Extraction and Hydrolysis}

Samples from the first phase of Experiment 2 were collected during the exponential growth phase of each species, i.e., T. amphioxeia on day 3 and the M. rubrum controls and Dinophysis species on day 7, in Falcon tubes of 15 or $50 \mathrm{~mL}$ and centrifuged (Sigma 3-18K, Fisher Bioblock Scientific, France), as in Experiment 1. Pellets from Experiment 1 and 2 were extracted twice, resuspended in $0.5 \mathrm{~mL} \mathrm{MeOH}$, vortexed, and sonicated at $45 \mathrm{KHz}$ for $15 \mathrm{~min}$. Then, $200 \mathrm{mg}$ of $200 \mu \mathrm{m}$ glass beads were added and the mixture placed in a Mixer Mill MM 400 (Retsch GmbH, Haan, Germany) for 30 min to disrupt the cells, centrifuged at $12,000 \times g$ and $4{ }^{\circ} \mathrm{C}$ for $10 \mathrm{~min}$ and the supernatant $(500 \mu \mathrm{L})$ filtered using $1.5 \mathrm{~mL}$ Eppendorf tubes with a $0.2 \mu \mathrm{m}$ mesh included.For the second part of Experiment 2, extractions of each Dinophysis species triplicates that were fed each M. rubrum were carried out. Cultures of M. rubrum strains and the cryptophyte on day 12 were already senescent and discarded. For quantification, a basic hydrolysis of the Dinophysis and M. rubrum pellets from both experiments was carried out to convert esters of the main toxin (OA, DTX, and PTX) into their parent toxins (free toxins) [100]). For this purpose, $250 \mu \mathrm{L}$ of methanol extracts of the samples were mixed with $30 \mu \mathrm{L}$ of $\mathrm{NaOH}$ in hermetic-closing opaque-glass tubes and heated at $75{ }^{\circ} \mathrm{C}$ for $40 \mathrm{~min}$. Samples were then left to cool down, their volumes verified and $30 \mu \mathrm{L}$ of $\mathrm{HCl}$ added before being stirred, and then filtered through a $0.2 \mu \mathrm{m}$ microfilter into $1.5 \mathrm{~mL}$ Eppendorf tubes, centrifuged $\left(12,000 \times \mathrm{g}, 10 \mathrm{~min}, 4{ }^{\circ} \mathrm{C}\right)$, and transferred to vials before injection.

\subsubsection{High Resolution Mass Spectral Analysis-System A: (QTOF 6550)}

UPLC-HRMS analyses were carried out with a UHPLC system (1290 Infinity II, Agilent technologies, Santa Clara, CA, USA) coupled to a high resolution time-of-flight mass spectrometer (Q-Tof 6550 iFunnel, Agilent technologies, CA, USA), equipped with a Dual Jet Stream ${ }^{\circledR}$ electrospray ionization (ESI) interface operating in both negative and positive mode in separate runs. Chromatographic separation was carried out on a reversed-phase $C_{18}$ Kinetex column $(100 \AA$, $2.6 \mu \mathrm{m}, 50 \times 2.1 \mathrm{~mm}$, Phenomenex, LePecq, France) at $40{ }^{\circ} \mathrm{C}$ using a mobile phase that was composed of water (A) and $95 \%$ acetonitrile/water (B) both containing $5 \mathrm{mM}$ ammonium formate and $50 \mathrm{mM}$ formic acid. The flow rate was set at $0.4 \mathrm{~mL} \mathrm{~min}^{-1}$ and the injection volume $3 \mu \mathrm{L}$. Separation was achieved using the following mobile phase gradient: from 10 to $50 \%$ B in $2 \mathrm{~min}$, to $90 \%$ B over the next 
$3 \mathrm{~min}$, held for $5 \mathrm{~min}$ before return to the initial condition (10\% B) in $0.5 \mathrm{~min}$, and a re-equilibration period $(10 \% \mathrm{~B})$ for $5.0 \mathrm{~min}$.

Mass spectral detection was carried out in full scan and targeted MS/MS mode in negative (ESI ${ }^{-}$) and positive $\left(\mathrm{ESI}^{+}\right)$ion acquisition. The full scan acquisition operated at a mass resolution of 40,000 Full Width at Half Maximum (FWHM) over a mass-to-charge ratio $(\mathrm{m} / \mathrm{z})$ range from 100 to 1700 with a scan rate of 2 spectra s $^{-1}$. The targeted MS/MS mode was performed in a Collision Induced Dissociation (CID) cell using a mass resolving power of 40,000 FWHM over the scan range $m / z$ from 50 to 1700 with a MS scan rate of 10 spectra s ${ }^{-1}$ and a MS/MS scan rate of 3 spectra s ${ }^{-1}$. Three different collision energies (i.e., 30, 50, and $70 \mathrm{eV}$ ) were applied to the precursor ions to obtain adequate fragmentation.

The conditions of the ESI source were set as follows: source temperature, $200{ }^{\circ} \mathrm{C}$; drying gas, $\mathrm{N}_{2}$; flow rate, $11 \mathrm{~mL} \mathrm{~min}{ }^{-1}$; sheath gas temperature, $350{ }^{\circ} \mathrm{C}$; sheath gas flow rate, $11 \mathrm{~mL} \mathrm{~min}{ }^{-1}$; nebulizer, 45 psig; capillary voltage, $3.5 \mathrm{kV}$; nozzle voltage, $500 \mathrm{~V}$. A calibration-check was carried out continuously over the entire run time using reference masses $\mathrm{m} / \mathrm{z} 121.0509$ (purine) and $\mathrm{m} / \mathrm{z} 922.0099$ (hexakis phosphazine).

Acquisition (see Table 4) was controlled by Mass Hunter software (Agilent Technologies, CA, USA). Raw data were processed using the Molecular Feature Extraction (MFE) algorithm of the Agilent Mass Hunter Qualitative Analysis software (version B.07.00, service pack 1).

\subsubsection{Low Resolution Tandem Mass Spectrometry: System B (API 4000 QTrap)}

UHPLC-LRMS/MS analyses were carried out with a UHPLC system (UFLC XR Nexera, Shimadzu, Tokyo, Japan) that was coupled to a hybrid triple quadrupole/ion-trap mass spectrometer (API 4000 QTrap, SCIEX, Redwood City, CA, USA), equipped with a turboV ${ }^{\circledR}$ ESI source.

Toxins were separated using the same chromatographic conditions, as described above (system A). The injection volume was set at $5 \mu \mathrm{L}$. For quantitation, the mass spectrometer was operated in multiple reactions monitoring (MRM) acquisition mode, scanning two transitions for each toxin. Positive and negative acquisition experiments were established using the following source settings: curtain gas set at $30 \mathrm{psi}\left(\mathrm{ESI}^{+}\right)$and $20 \mathrm{psi}\left(\mathrm{ESI}^{-}\right)$, ion spray at $5500 \mathrm{~V}\left(\mathrm{ESI}^{+}\right)$, and $-4500 \mathrm{~V}\left(\mathrm{ESI}^{-}\right)$, Turbogas temperature of $550{ }^{\circ} \mathrm{C}$, gas 1 and 2 set, respectively, at 40 and $50 \mathrm{psi}$, and an entrance potential of $10 \mathrm{~V}$. Pectenotoxins (PTX) were analyzed in positive mode and OA group toxins in negative ionization mode (Table 4). Data acquisition and quantification were carried out using Analyst software version 1.6.2 (SCIEX, Redwood City, CA, USA). ANOVA was carried out at the end of the experiments to evaluate the statistical significance of toxin content per cell in Experiment 2.

Certified calibration solutions were purchased from the National Research Council Canada (NRCC, Halifax, NS, Canada): PTX2, OA, DTX1, and -2. HPLC grade methanol, acetonitrile, and formic acid (98\%) were obtained from Sigma Aldrich (Steinheim, Germany). Ammonium formate was acquired from Fluka (St. Louis, MO, USA). Milli-Q water was obtained in-house to $18 \mathrm{M} \Omega \mathrm{cm}^{-1}$ quality, using a Milli-Q integral 3 system (Merck Millipore, Guyancourt, France). For HRMS, acetonitrile and high purity water were obtained from Fisher Scientific (Illkirch, France). 
Table 4. Optimized parameters for the liquid-chromatography coupled to low resolution mass spectrometry (LC-LRMS/MS). MS acquisition parameters for API4000QTrap (System B). * fragment ion used for quantitation.

\begin{tabular}{|c|c|c|c|c|c|c|}
\hline Toxin & $\begin{array}{l}\text { Ionization } \\
\text { Mode }\end{array}$ & Ion & $\begin{array}{l}\text { Parent Ion } \\
\quad(\mathrm{m} / \mathrm{z})\end{array}$ & $\begin{array}{l}\text { Fragment } \\
\text { Ions }(m / z)\end{array}$ & DP (V) & $\mathrm{CE}(\mathrm{eV})$ \\
\hline OA & $\mathrm{ESI}^{-}$ & {$[\mathrm{M}-\mathrm{H}]^{-}$} & 803.4 & $\begin{array}{c}255.1^{*} \\
113.1\end{array}$ & -170 & $\begin{array}{l}-62 \\
-92\end{array}$ \\
\hline \multirow{2}{*}{ DTX2 } & \multirow{2}{*}{$\mathrm{ESI}^{-}$} & \multirow{2}{*}[\mathrm{M}-\mathrm{H}]{$^{-}$} & \multirow{2}{*}{803.4} & $255.1^{*}$ & \multirow{2}{*}{-170} & -62 \\
\hline & & & & 113.1 & & -92 \\
\hline \multirow{2}{*}{ DTX1 } & \multirow{2}{*}{$\mathrm{ESI}^{-}$} & \multirow{2}{*}[\mathrm{M}-\mathrm{H}]{$^{-}$} & \multirow{2}{*}{817.5} & $255.1^{*}$ & \multirow{2}{*}{-170} & -68 \\
\hline & & & & 113.1 & & -92 \\
\hline \multirow{3}{*}{ PTX2 } & \multirow{3}{*}{$\mathrm{ESI}^{+}$} & \multirow{3}{*}[\mathrm{M}+\mathrm{NH}_{4}]{$^{+}$} & \multirow{3}{*}{876.6} & $823.6^{*}$ & \multirow{3}{*}{91} & 31 \\
\hline & & & & 805.6 & & 37 \\
\hline & & & & 213.6 & & 55 \\
\hline \multirow{3}{*}{ PTX2sa and 7-epi PTX2sa } & \multirow{3}{*}{$\mathrm{ESI}^{+}$} & \multirow{3}{*}[\mathrm{M}+\mathrm{NH}_{4}]{$^{+}$} & \multirow{3}{*}{894.6} & $823.6^{*}$ & \multirow{3}{*}{91} & 31 \\
\hline & & & & 805.6 & & 37 \\
\hline & & & & 213.6 & & 55 \\
\hline \multirow{3}{*}{ PTX1, PTX4 and PTX11 } & \multirow{3}{*}{$\mathrm{ESI}^{+}$} & \multirow{3}{*}[\mathrm{M}+\mathrm{NH}_{4}]{$^{+}$} & \multirow{3}{*}{892.6} & $839.6^{*}$ & \multirow{3}{*}{91} & 31 \\
\hline & & & & 821.4 & & 37 \\
\hline & & & & 213.6 & & 55 \\
\hline \multirow{3}{*}{ PTX3 } & \multirow{3}{*}{$\mathrm{ESI}^{+}$} & \multirow{3}{*}[\mathrm{M}+\mathrm{NH}_{4}]{$^{+}$} & \multirow{3}{*}{890.5} & $873.6^{*}$ & \multirow{3}{*}{91} & 31 \\
\hline & & & & 856.6 & & 37 \\
\hline & & & & 213.6 & & 55 \\
\hline \multirow{3}{*}{ PTX6 and PTX7 } & \multirow{3}{*}{$\mathrm{ESI}^{+}$} & \multirow{3}{*}[\mathrm{M}+\mathrm{NH}_{4}]{$^{+}$} & \multirow{3}{*}{906.6} & $871.6^{*}$ & & 31 \\
\hline & & & & 853.6 & 91 & 37 \\
\hline & & & & 213.6 & & 55 \\
\hline & & & & $857.6^{*}$ & & 31 \\
\hline PTX12 and PTX14 & $\mathrm{ESI}^{+}$ & {$\left[\mathrm{M}+\mathrm{NH}_{4}\right]^{+}$} & 874.6 & 840.6 & 91 & 37 \\
\hline & & & & 213.6 & & 55 \\
\hline
\end{tabular}

\subsection{Data Treatment for Non-Targeted Liquid Chromatography High Resolution Mass Spectrometry}

\subsubsection{Feature Identification and Variables' Selection}

Features are distinct ion clusters, belonging either to compounds or to provisionally identified metabolites, which possess an abundance, a mass, a retention time, and, if present in available databases, a score thatallows their qualitative identification and assignment of a sum formula. Features were extracted from raw data files by a molecular feature extraction (MFE) algorithm using a Mass Hunter Workstation Qualitative Analysis Software (Agilent Technologies, Santa Clara, CA, USA) to create a work-flow to subtract procedural blanks in batches of samples (ESI ${ }^{+}$and $\mathrm{ESI}^{-}$ionization modes in extracted and hydrolyzed samples). An abundance cut-off value was selected so that features with peak heights of 5000 or higher were transformed into compound exchange format (.cef) files with the Mass Hunter Reprocessor, and were subsequently analyzed with Mass Profiler Professional software (MPP, version B 13.1.1) to identify statistically meaningful differences of features between groups. Compound alignment parameters were: $\mathrm{RT}=0.0 \%+0.15 \mathrm{~min}$ and mass $=15.0 \mathrm{ppm}+2.0 \mathrm{mDa}$.

Resulting abundance data were normalized using external scalars of each triplicate sample group. After this normalization, organisms were treated as equal-sized organisms and size effects on the results were avoided (e.g., compounds abundance on the smallest organism-in this study, Teleaulax amphioxeia-would be too small to allow for a comparison with the largest organism, Dinophysis acuta in this case. External scalars were calculated, as follows:

$$
\mathrm{B}=\text { Biovolume } \mathrm{X} / \text { Biovolume Teleaulax }
$$




$$
\begin{gathered}
\mathrm{A}=\mathrm{N}_{\text {tot }} \times(1) \\
\mathrm{S}=(2) / \mathrm{N}_{\text {totTeleaulax }}
\end{gathered}
$$

where $\mathrm{B}$ is the biovolume of species $\mathrm{X}$ normalized in relation to that of Teleaulax, $\mathrm{A}$ is the normalized biovolume of the total number of cells in the sample $\left(\mathrm{N}_{\mathrm{tot}}\right), \mathrm{S}$ is the external scalar that was used for abundance data extracted from LC-HRMS.

Compounds satisfying a fold change cut-off of 2.0 and a $100 \%$ of frequency in each sample group triplicate were used to identify common and unique features within or between groups.

Sample quality assurance was tested by Principal Component Analysis (PCA). Significance testing was carried out using one-way and two-way ANOVA, an asymptotic $p$-value computation, a multiple testing correction of Benjamini-Hochberg, and a $p$-value cut-off of 0.001 .

Similar and specific compounds were selected manually and verified with the Find Similar Entities tool displaying expression profiles of entities whose correlation coefficients to the target profiles were above the correlation cut-off range $(0.5-0.85,1.0)$ using an Euclidean similarity measure. $P$-values for "in both positive and negative ESI modes" were calculated with MPP, according to the variables "origin" (Spain and Denmark) and "feeding-status" (well-fed and prey-limited) for all the features in the samples. Samples list and grouping following the foregoing variables are shown in Table S12. Features were grouped into one variable depending on their distribution pattern. For features that were fulfilling the same conditions as above, only $p$-values of $<0.001$ were used.

Resulting compounds were identified with the Agilent Mass Hunter ID Browser B.07.00 against databases (METLIN and the Dictionary of Marine Natural Products) with a mass-match tolerance of $2.00 \mathrm{ppm}$, and formulae were generated with the Molecular Formula Generator (MFG). Compound identification default settings were as follows: mass and retention time (RT) score were 100.00; isotope abundance and spacing scores were 80.00 . Selected expected data variations were: $1.0 \mathrm{mDa}+2.0 \mathrm{ppm}$ for MS mass, MS isotope abundance of 7.5\%, MS/MS mass of $5.0 \mathrm{mDa}+7.5 \mathrm{ppm}$, and a RT of $0.115 \mathrm{~min}$. For positive ions, neutral water losses and $\mathrm{H}^{+}, \mathrm{Na}^{+} ; \mathrm{K}^{+}$, and $\mathrm{NH}_{4}{ }^{+}$adducts were selected as charge carriers, whereas for negative ions, neutral water losses, and $\mathrm{H}^{-}, \mathrm{Cl}^{-}, \mathrm{Br}^{-}, \mathrm{HCOO}^{-}, \mathrm{CH}_{3} \mathrm{COO}^{-}$, and $\mathrm{CF} 3 \mathrm{COO}^{-}$were selected as charge carriers.

Compounds were clustered once they were identified following (a) "physiological meaning": common and specific compounds of all and each organism, respectively, and (b) "compounds first found in other marine/terrestrial organisms" that were identified either in both or particularly in one of the Dinophysis species.

\section{Conclusions}

Metabolomic profiling allowed for us to differentiate Dinophysis species and treatments ("prey origin" and "nutritional status", especially in D. acuminata), and some of the compounds that were involved were tentatively identified. Non-targeted analyses serve as a powerful screening tool and led to the identification of a new diol ester in D. acuta. The variable "species" gave the highest separation between groups of D. acuminata and D. acuta, followed by the variable "prey origin" (Danish and Spanish M. rubrum strain). Future studies should help in building up a "Dinophysis-metabolites library" initiated by this study, to confirm or to reject some of the hypotheses that are formulated in this paper. This library would provide valuable information regarding (i) metabolic fingerprints and pathways; (ii) predator-prey-recognition mechanisms related to target metabolites; and, (iii) clarify biogeographical distributions as well as the biological origin of compounds often identified first in higher, filter-feeding marine organisms, such as sponges.

Supplementary Materials: The following are available online at http:/ /www.mdpi.com/1660-3397/16/5/143/s1. Compounds highlighted in blue color correspond to compounds with an annotation immediately on the right of the row in which they are placed. Table S1A: Compounds common to all species in Experiment 1; Table S1B: Compounds common to all species in Experiment 2; Table S2: T. amphioxeia compounds from Experiment $2\left(\mathrm{ESI}^{-}\right)$; Table S3A: Compounds occurring in both species of Dinophysis but specific to "prey origin" (ESI ${ }^{+}$), fold-change $>2$, $p<0.001$. Table S3B: Compounds differing between the two species of Dinophysis with fold-change $>2, p<0.001$ 
$\left(\mathrm{ESI}^{+}\right.$), Table S3C: Compounds common to both species of Dinophysis, differentially expressed (fold-change $>2$, $p<0.001)$ with interaction between "prey origin" and "species" $\left(\mathrm{ESI}^{+}\right)$; Table S4A: Compounds common to both species of Dinophysis, differentially expressed (fold-change $>2, p<0.001$ ) as a function of "prey origin" $\left(\mathrm{ESI}^{-}\right.$); Table S4B: Compounds common to both species of Dinophysis, differentially expressed (fold-change $>2, p<0.001)$ as a function of "species" $\left(\mathrm{ESI}^{-}\right)$; Table S4C: Compounds common to both species of Dinophysis differentially expressed (fold-change $>2, p<0.001$ ) with interactions between "prey origin" and "species" $\left(\mathrm{ESI}^{-}\right)$; Table S5A: Statistically significant compounds common to both species of Dinophysis presented as a function of "species", "prey origin" and "nutritional status" in ESI ${ }^{-}$; Table S5B: Statistically significant compounds common to both species of Dinophysis presented as a function of "species", "prey origin" and "nutritional status" in ESI"; Table S6A: Compounds specific to in Dinophysis acuta (fold-change $>2, p<0.001$ ) according to "prey origin" and "nutritional status" in ESI- , Table S6B: Compounds specific to Dinophysis acuta (fold-change $>2, p<0.001$ ) as a function of "prey origin" and "nutritional status" in ESI ${ }^{+}$, Table S7A: Compounds specific to Dinophysis acuminata (i.e., differentially expressed with a fold-change $>2$ and $p<0.001$ ) according to "prey origin" and "nutritional status" in $\mathrm{ESI}^{-}$; Table S7B: Compounds found only $(p<0.001)$ in Dinophysis acuminata according to "prey origin" and "nutritional status" in ESI ${ }^{+}$; Table S8: The only statistically significant compound found in Dinophysis acuta in well-fed conditions (Danish M. rubrum)" in ESI ${ }^{-}$; Table S9A: Statistically significant compounds found in Dinophysis acuta in prey-limited conditions (Danish M. rubrum)" in ESI ${ }^{-}$; Table S9B: Compounds specific to Dinophysis acuta (fold-change $>2, p<0.001$ ) in prey-limited conditions (Danish M. rubrum)" in ESI ${ }^{+}$; Table S10: Compounds specific to Dinophysis acuminata (fold-change $>2, p<0.001$ ) in well-fed conditions (Danish M. rubrum)" in $\mathrm{ESI}^{-}$; Table S11A: Compounds specific to Dinophysis acuminata (fold-change $>2, p<0.001$ ) in prey-limited conditions (Danish M. rubrum)" in ESI ${ }^{-}$; Table S11B: Compounds specific to Dinophysis acuminata (fold-change $>2$, $p<0.001$ ) in prey-limited conditions (Danish M. rubrum)" in $\mathrm{ESI}^{+}$; Table S12: Samples resulting from Experiments 1 and 2 clustered according variables "Species", "Prey origin" and "Nutritional Status". PB: Procedural Blank; QC: Quality control; n/a: non-applicable; TA: Teleaulax amphioxeia; MR: Mesodinium rubrum; DATA: Dinophysis acuminata; DA: Dinophysis acuta.

Author Contributions: M.G.-P., F.R., B.R., P.H. conceived and designed the experiments; M.G.-P., M.S., A.A. performed the experiments; F.R. contributed with cultures management and transport from Vigo to Nantes; M.G.-P., M.S., A.A., P.H. analyzed the data; M.G.-P., B.R., P.H. wrote the paper.

Acknowledgments: We thank Virginie Rainbault for technical support, Pilar Rial for T. amphioxeia micrograph and Per Juel Hansen (University of Copenhagen, Denmark) for cultures of Mesodinium rubrum (Mr-DK2009). This study was funded by Spanish DINOMA (RETOS Programme, CGL2013-48861-R) and MARBioFEED (ERANET Marine Biotechnlogy, PCIN-2015-252) and French COSELMAR (2012-09684 Région des Pays de la Loire, France) projects. M. García-Portela was supported by a mobility grant from the Spanish Ministry MINEICO (grant number EEBB-I-16-11141) to carry out these experiments in cooperation with the Phycotoxins Group (Ifremer, Nantes), and A. Altenburger by a grant from The Danish Council for Independent Research to Per Juel Hansen (grant number 4181-00484). This research article is part of M. García-Portela's PhD thesis, affiliated to the "Marine Science, Technology and Management" doctoral programme at the University of Vigo and supported by a PhD contract (BES-2014-067832).

Conflicts of Interest: The authors declare no conflict of interest.

\section{References}

1. Van Egmond, H.; Aune, T.; Lassus, P.; Speijers, G.; Waldock, M. Paralytic and diarrhoeic shellfish poisons: Occurrence in Europe, toxicity, analysis and regulation. J. Nat. Toxins 1993, 2, 41-83.

2. Reguera, B.; Riobó, P.; Rodríguez, F.; Díaz, P.; Pizarro, G.; Paz, B.; Franco, J.; Blanco, J. Dinophysis toxins: Causative organisms, distribution and fate in shellfish. Mar. Drugs 2014, 12, 394-461. [CrossRef] [PubMed]

3. López, B.D.; Methion, S. The impact of shellfish farming on common bottlenose dolphins' use of habitat. Mar. Biol. 2017, 164, 83. [CrossRef]

4. Blanco, J.; Correa, J.; Muñíz, S.; Mariño, C.; Martín, H.; Arévalo, F. Evaluación del impacto de los métodos y niveles utilizados para el control de toxinas en el mejillón. Revista Galega dos Recursos Mariños 2013, 3, 1-55. (In Spanish)

5. Park, M.G.; Kim, S.; Kim, H.S.; Myung, G.; Kang, Y.G.; Yih, W. First successful culture of the marine dinoflagellate Dinophysis acuminata. Aquat. Microb. Ecol. 2006, 45, 101-106. [CrossRef]

6. Riisgaard, K.; Hansen, P.J. Role of food uptake for photosynthesis, growth and survival of the mixotrophic dinoflagellate Dinophysis acuminata. Mar. Ecol. Prog. Ser. 2009, 381, 51-62. [CrossRef]

7. Kim, E.; Archibald, J.M. Plastid evolution: Gene transfer and the maintenance of 'stolen' organelles. BMC Biol. 2010, 8, 73. [CrossRef] [PubMed]

8. Hattenrath-Lehmann, T.; Gobler, C.J. The contribution of inorganic and organic nutrients to the growth of a North American isolate of the mixotrophic dinoflagellate, Dinophysis acuminata. Limnol. Oceanogr. 2015, 60, 1588-1603. [CrossRef] 
9. Hansen, P.J. Dinophysis-A planktonic dinoflagellate genus which can act both as a prey and a predator of a ciliate. Mar. Ecol. Prog. Ser. 1991, 69, 201-204. [CrossRef]

10. Wisecaver, J.H.; Hackett, J.D. Transcriptome analysis reveals nuclear-encoded proteins for the maintenance of temporary plastids in the dinoflagellate Dinophysis acuminata. BMC Genom. 2010, 11, 366. [CrossRef] [PubMed]

11. Garcia-Cuetos, L.; Moestrup, Ø.; Hansen, P.J.; Daugbjerg, N. The toxic dinoflagellate Dinophysis acuminata harbors permanent chloroplasts of cryptomonad origin, not kleptochloroplasts. Harmful Algae 2010, 9, $25-38$. [CrossRef]

12. Park, M.G.; Kim, M.; Kim, S.; Yih, W. Does Dinophysis caudata (Dinophyceae) have permanent plastids? J. Phycol. 2010, 46, 236-242. [CrossRef]

13. Raho, N.; Jaén, D.; Mamán, L.; Rial, P.; Marín, I. psbA based molecular analysis of cross-feeding experiments suggests that Dinophysis acuta does not harbour permanent plastids. Harmful Algae 2014, 35, 20-28. [CrossRef]

14. Takahashi, Y.; Takishita, K.; Koike, K.; Maruyama, T.; Nakayama, T.; Kobiyama, A.; Ogata, T. Development of molecular probes for Dinophysis (Dinophyceae) plastid: A tool to predict blooming and explore plastid origin. Mar. Biotechnol. 2005, 7, 95-103. [CrossRef] [PubMed]

15. Minnhagen, S.; Janson, S. Genetic analyses of Dinophysis spp. support kleptoplastidy. FEMS Microbiol. Ecol. 2006, 57, 47-54. [CrossRef] [PubMed]

16. Nishitani, G.; Nagai, S.; Baba, K.; Kiyokawa, S.; Kosaka, Y.; Miyamura, K.; Nishikawa, T.; Sakurada, K.; Shinada, A.; Kamiyama, T. High-level congruence of Myrionecta rubra prey and Dinophysis species plastid identities as revealed by genetic analyses of isolates from Japanese coastal waters. Appl. Environ. Microbiol. 2010, 76, 2791-2798. [CrossRef] [PubMed]

17. Kim, M.; Nam, S.W.; Shin, W.; Coats, D.W.; Park, M.G. Dinophysis caudata (Dinophyceae) sequesters and retains plastids from the mixotrophic ciliate prey Mesodinium rubrum. J. Phycol. 2012, 48, 569-579. [CrossRef] [PubMed]

18. Stern, R.; Amorim, A.; Bresnan, E. , Diversity and plastid types in Dinophysis acuminata complex (Dinophyceae) in Scottish waters. Harmful Algae 2014, 39, 223-231. [CrossRef]

19. Rial, P.; Laza-Martínez, A.; Reguera, B.; Raho, N.; Rodríguez, F. Origin of cryptophyte plastids in Dinophysis from Galician waters: Results from field and culture experiments. Aquat. Microb. Ecol. 2015, 76, 163-174. [CrossRef]

20. Herfort, L.; Maxey, K.; Voorhees, I.; Simon, H.M.; Grobler, K.; Peterson, T.D.; Zuber, P. Use of highly specific molecular markers reveals positive correlation between abundances of Mesodinium cf. major and its preferred prey, Teleaulax amphioxeia, during red water blooms in the Columbia river estuary. J. Eukaryot. Microbiol. 2017, 64, 740-755. [PubMed]

21. Stoecker, D.K.; Johnson, M.D.; de Vargas, C.; Not, F. Acquired phototrophy in aquatic protists. Aquat. Microb. Ecol. 2009, 57, 279-310. [CrossRef]

22. Reguera, B.; Velo-Suárez, L.; Raine, R.; Park, M.G. Harmful Dinophysis species: A. review. Harmful Algae 2012, 14, 87-106. [CrossRef]

23. Gustafson, D.E.; Stoecker, D.K.; Johnson, M.D.; Van Heukelem, W.F.; Sneider, K. Cryptophyte algae are robbed of their organelles by the marine ciliate Mesodinium rubrum. Nature 2000, 405, 1049-1052. [CrossRef] [PubMed]

24. Taylor, F.; Blackbourn, D.; Blackbourn, J. The red-water ciliate Mesodinium rubrum and its "incomplete symbionts": A review including new ultrastructural observations. J. Fish. Res. Board Can. 1971, 28, 391-407. [CrossRef]

25. Hansen, P.J.; Moldrup, M.; Tarangkoon, W.; Garcia-Cuetos, L.; Moestrup, Ø. Direct evidence for symbiont sequestration in the marine red tide ciliate Mesodinium rubrum. Aquat. Microb. Ecol. 2012, 66, 63-75. [CrossRef]

26. Kim, G.H.; Han, J.H.; Kim, B.; Han, J.W.; Nam, S.W.; Shin, W.; Park, J.W.; Yih, W. Cryptophyte gene regulation in the kleptoplastidic, karyokleptic ciliate Mesodinium rubrum. Harmful Algae 2016, 52, 23-33. [CrossRef] [PubMed]

27. Park, M.; Park, J.; Kim, M.; Yih, W. Plastid retention and functionality in the dinoflagellates Dinophysis acuminata and Dinophysis caudata. J. Phycol. 2007, 43, 7-8. 
28. Johnson, M.D.; Beaudoin, D.J.; Laza-Martinez, A.; Dyhrman, S.T.; Fensin, E.; Lin, S.; Merculief, A.; Nagai, S.; Pompeu, M.; Setälä, O. The genetic diversity of Mesodinium and associated Cryptophytes. Front. Microbiol. 2016, 7. [CrossRef] [PubMed]

29. Goulitquer, S.; Potin, P.; Tonon, T. Mass spectrometry-based metabolomics to elucidate functions in marine organisms and ecosystems. Mar. Drugs 2012, 10, 849-880. [CrossRef] [PubMed]

30. Peng, B.; Li, H.; Peng, X.X. Functional metabolomics: From biomarker discovery to metabolome reprogramming. Protein Cell 2015, 6, 628-637. [CrossRef] [PubMed]

31. Singh, S.; Kate, B.N.; Banerjee, U. Bioactive compounds from cyanobacteria and microalgae: An overview. Crit. Rev. Biotechnol. 2005, 25, 73-95. [CrossRef] [PubMed]

32. Bundy, J.G.; Davey, M.P.; Viant, M.R. Environmental metabolomics: A critical review and future perspectives. Metabolomics 2009, 5, 3. [CrossRef]

33. Viant, M.R. Recent developments in environmental metabolomics. Mol. BioSyst. 2008, 4, 980-986. [CrossRef] [PubMed]

34. Huseby, S.; Degerlund, M.; Zingone, A.; Hansen, E. Metabolic fingerprinting reveals differences between northern and southern strains of the cryptic diatom Chaetoceros socialis. Eur. J. Phycol. 2012, 47, 480-489. [CrossRef]

35. Cachet, N.; Genta-Jouve, G.; Ivanisevic, J.; Chevaldonné, P.; Sinniger, F.; Culioli, G.; Pérez, T.; Thomas, O.P. Metabolomic profiling reveals deep chemical divergence between two morphotypes of the zoanthid Parazoanthus axinellae. Sci. Rep. 2015, 5, 8282. [CrossRef] [PubMed]

36. Tachibana, K.; Scheuer, P.J.; Tsukitani, Y.; Kikuchi, H.; Van Engen, D.; Clardy, J.; Gopichand, Y.; Schmitz, F.J. Okadaic acid, a cytotoxic polyether from two marine sponges of the genus Halichondria. J. Am. Chem. Soc. 1981, 103, 2469-2471. [CrossRef]

37. Murakami, Y.; Oshima, Y.; Yasumoto, T. Identification of okadaic acid as a toxic component of a marine dinoflagellate Prorocentrum lima. Bull. Jpn. Soc. Sci. Fish. 1982, 48, 69-72. [CrossRef]

38. Nagai, H.; Torigoe, K.; Satake, M.; Murata, M.; Yasumoto, T.; Hirota, H. Gambieric acids: Unprecedented potent antifungal substances isolated from cultures of a marine dinoflagellate Gambierdiscus toxicus. J. Am. Chem. Soc. 1992, 114, 1102-1103. [CrossRef]

39. Sogawa, K.; Matsuda, M.; Okutani, K. Induction of apoptosis by a marine microalgal polysaccharide in a human leukemic cell line. J. Mar. Biotechnol. 1998, 6, 241-243. [PubMed]

40. Umemura, K.; Yanase, K.; Suzuki, M.; Okutani, K.; Yamori, T.; Andoh, T. Inhibition of DNA topoisomerases I and II, and growth inhibition of human cancer cell lines by a marine microalgal polysaccharide. Biochem. Pharmacol. 2003, 66, 481-487. [CrossRef]

41. Kobayashi, J.; Tsuda, M. Bioactive products from Okinawan marine micro-and macroorganisms. Phytochem. Rev. 2004, 3, 267-274. [CrossRef]

42. Kerr, R.G.; Kerr, S.S. Marine natural products as therapeutic agents. Expert. Opin. Ther. Pat. 1999, 9, 1207-1222. [CrossRef]

43. Blunt, J.W.; Munro, M.H. Dictionary of Marine Natural Products with CD-ROM, 1st ed.; Chapman and Hall/CRC: Boca Raton, FL, USA, 2007; pp. 1-2536, ISBN 978-0-8493-8216-1.

44. Smith, C.A.; O’Maille, G.; Want, E.J.; Qin, C.; Trauger, S.A.; Brandon, T.R.; Custodio, D.E.; Abagyan, R.; Siuzdak, G. METLIN: A metabolite mass spectral database. Ther. Drug. Monit. 2005, 27, 747-751. [CrossRef] [PubMed]

45. Garcia-Cuetos, L.; Moestrup, Ø.; Hansen, P.J. Studies on the genus Mesodinium II. Ultrastructural and molecular investigations of five marine species help clarifying the taxonomy. J. Eukaryot. Microbiol. 2012, 59, 374-400. [CrossRef] [PubMed]

46. Vale, P.; Sampayo, M.A.D.M. Esterification of DSP toxins by Portuguese bivalves from the Northwest coast determined by LC-MS-A widespread phenomenon. Toxicon 2002, 40, 33-42. [CrossRef]

47. Sibat, M.; García-Portela, M.; Hess, P. First identification of a C9-diol-ester of okadaic acid in Dinophysis acuta from Galician Rías Baixas (NW Spain). Toxicon (under review).

48. Hiraga, Y.; Kaku, K.; Omoda, D.; Sugihara, K.; Hosoya, H.; Hino, M. A new digalactosyl diacylglycerol from a cultured marine dinoflagellate Heterocapsa circularisquama. J. Nat. Prod. 2002, 65, 1494-1496. [CrossRef] [PubMed] 
49. Boudière, L.; Michaud, M.; Petroutsos, D.; Rébeillé, F.; Falconet, D.; Bastien, O.; Roy, S.; Finazzi, G.; Rolland, N.; Jouhet, J. Glycerolipids in photosynthesis: Composition, synthesis and trafficking. Biochim. Biophys. Acta Bioenerg. 2014, 1837, 470-480. [CrossRef] [PubMed]

50. LeBlond, J.D.; Menn, F.M.; Schultz, T.W.; Sayler, G.S. Structure-toxicity assessment of metabolites of the aerobic bacterial transformation of substituted naphthalenes. Environ. Toxicol. Chem. 2000, 19, 1235-1246.

51. Joyard, J.; Teyssier, E.; Miège, C.; Berny-Seigneurin, D.; Maréchal, E.; Block, M.A.; Dorne, A.-J.; Rolland, N.; Ajlani, G.; Douce, R. The biochemical machinery of plastid envelope membranes. Plant. Physiol. 1998, 118, 715-723. [CrossRef] [PubMed]

52. Sakurai, I.; Hagio, M.; Gombos, Z.; Tyystjärvi, T.; Paakkarinen, V.; Aro, E.-M.; Wada, H. Requirement of phosphatidylglycerol for maintenance of photosynthetic machinery. Plant. Physiol. 2003, 133, 1376-1384. [CrossRef] [PubMed]

53. Härtel, H.; Dörmann, P.; Benning, C. DGD1-independent biosynthesis of extraplastidic galactolipids after phosphate deprivation in Arabidopsis. Proc. Natl. Acad. Sci. USA 2000, 97, 10649-10654. [CrossRef] [PubMed]

54. Van Mooy, B.A.; Fredricks, H.F.; Pedler, B.E.; Dyhrman, S.T.; Karl, D.M.; Koblížek, M.; Lomas, M.W.; Mincer, T.J.; Moore, L.R.; Moutin, T. Phytoplankton in the ocean use non-phosphorus lipids in response to phosphorus scarcity. Nature 2009, 458, 69-72. [CrossRef] [PubMed]

55. Lasek-Nesselquist, E.; Wisecaver, J.H.; Hackett, J.D.; Johnson, M.D. Insights into transcriptional changes that accompany organelle sequestration from the stolen nucleus of Mesodinium rubrum. BMC Genom. 2015, 16, 805. [CrossRef] [PubMed]

56. Dawaliby, R.; Trubbia, C.; Delporte, C.; Noyon, C.; Ruysschaert, J.-M.; Van Antwerpen, P.; Govaerts, C. Phosphatidylethanolamine is a key regulator of membrane fluidity in eukaryotic cells. J. Biol. Chem. 2016, 291, 3658-3667. [CrossRef] [PubMed]

57. Hakomori, S. Structure, organization, and function of glycosphingolipids in membrane. Curr. Opin. Hematol. 2003, 10, 16-24. [CrossRef] [PubMed]

58. Gong, W.; Browne, J.; Hall, N.; Schruth, D.; Paerl, H.; Marchetti, A. Molecular insights into a dinoflagellate bloom. ISME J. 2016, 11, 439. [CrossRef] [PubMed]

59. Mansour, M.P.; Volkman, J.K.; Blackburn, S.I. The effect of growth phase on the lipid class, fatty acid and sterol composition in the marine dinoflagellate, Gymnodinium sp. in batch culture. Phytochemistry 2003, 63, 145-153. [CrossRef]

60. Fujita, Y. Protochlorophyllide reduction: A key step in the greening of plants. Plant. Cell. Physiol. 1996, 37, 411-421. [CrossRef] [PubMed]

61. Snyder, R.; Gibbs, P.; Palacios, A.; Abiy, L.; Dickey, R.; Lopez, J.V.; Rein, K. Polyketide synthase genes from marine dinoflagellates. Mar. Biotechnol. 2003, 5, 1-12. [PubMed]

62. Snyder, R.V.; Guerrero, M.A.; Sinigalliano, C.D.; Winshell, J.; Perez, R.; Lopez, J.V.; Rein, K.S. Localization of polyketide synthase encoding genes to the toxic dinoflagellate Karenia brevis. Phytochemistry 2005, 66, 1767-1780. [CrossRef] [PubMed]

63. Yu, S.; Deng, Z.; van Ofwegen, L.; Proksch, P.; Lin, W. 5,8-Epidioxysterols and related derivatives from a Chinese Soft Coral Sinularia flexibilis. Steroids 2006, 71, 955-959. [CrossRef] [PubMed]

64. Imbs, A.B.; Latyshev, N.A. Fatty acid composition as an indicator of possible sources of nutrition for soft corals of the genus Sinularia (Alcyoniidae). J. Mar. Biol. Assoc. UK 2012, 92, 1341-1347. [CrossRef]

65. Shimizu, Y.; Chou, H.N.; Bando, H.; Van Duyne, G.; Clardy, J. Structure of brevetoxin A (GB-1 toxin), the most potent toxin in the Florida red tide organism Gymnodinium breve (Ptychodiscus brevis). J. Am. Chem. Soc. 1986, 108, 514-515. [CrossRef] [PubMed]

66. Larsen, K.; Petersen, D.; Wilkins, A.L.; Samdal, I.A.; Sandvik, M.; Rundberget, T.; Goldstone, D.; Arcus, V.; Hovgaard, P.; Rise, F. Clarification of the C-35 stereochemistries of dinophysistoxin-1 and dinophysistoxin-2 and its consequences for binding to protein phosphatase. Chem. Res. Toxicol. 2007, 20, 868-875. [CrossRef] [PubMed]

67. Lu, C.-K.; Chou, H.N.; Lee, C.K.; Lee, T.H. Prorocentin, a new polyketide from the marine dinoflagellate Prorocentrum lima. Org. Lett. 2005, 7, 3893-3896.

68. Chill, L.; Berrer, N.; Benayahu, Y.; Kashman, Y. Eunicellin diterpenes from two Kenyan soft corals. J. Nat. Prod. 2005, 68, 19-25. [CrossRef] [PubMed] 
69. Ovenden, S.P.; Capon, R.J. Nuapapuin A and sigmosceptrellins D and E: New norterpene cyclic peroxides from a southern Australian marine sponge, Sigmosceptrella sp. J. Nat. Prod. 1999, 62, 214-218. [CrossRef] [PubMed]

70. Cardellina, J.H.; Marner, F.J.; Moore, R.E. Malyngamide A, a novel chlorinated metabolite of the marine cyanophyte Lyngbya majuscula. J. Am. Chem. Soc. 1979, 101, 240-242. [CrossRef]

71. Hansen, F.C.; Witte, H.J.; Passarge, J. Grazing in the heterotrophic dinoflagellate Oxyrrhis marina: Size selectivity and preference for calcified Emiliania huxleyi cells. Aquat. Microb. Ecol. 1996, 10, 307-313. [CrossRef]

72. Naustvoll, L.J. Prey size spectra and food preferences in thecate heterotrophic dinoflagellates. Phycologia 2000, 39, 187-198. [CrossRef]

73. Tong, M.; Zhou, Q.; David, K.M.; Jiang, T.; Qi, Y.; Donald, A.M. Culture techniques and growth characteristics of Dinophysis acuminata and its prey. Chin. J. Oceanol. Limnol. 2010, 28, 1230-1239. [CrossRef]

74. Nagai, S.; Suzuki, T.; Nishikawa, T.; Kamiyama, T. Differences in the production and excretion kinetics of okadaic acid, dinophysistoxin-1, and pectenotoxin-2 between cultures of Dinophysis acuminata and Dinophysis fortii isolated from Western Japan. J. Phycol. 2011, 47, 1326-1337. [CrossRef] [PubMed]

75. Pizarro, G.; Escalera, L.; González-Gil, S.; Franco, J.; Reguera, B. Growth, behaviour and cell toxin quota of Dinophysis acuta during a daily cycle. Mar. Ecol. Prog. Ser. 2008, 353, 89-105. [CrossRef]

76. Fernández, M.L.; Reguera, B.; González-Gil, S.; Míguez, A. Pectenotoxin-2 in single-cell isolates of Dinophysis caudata and Dinophysis acuta from the Galician Rías (NW Spain). Toxicon 2006, 48, 477-490. [CrossRef] [PubMed]

77. Martins, C.A.; Kulis, D.; Franca, S.; Anderson, D.M. The loss of PSP toxin production in a formerly toxic Alexandrium lusitanicum clone. Toxicon 2004, 43, 195-205. [CrossRef] [PubMed]

78. Fiehn, O. Metabolomics-The link between genotypes and phenotypes. In Functional Genomics; Springer: Berlin/Heidelberg, Germany, 2002; pp. 155-171.

79. Sardans, J.; Penuelas, J.; Rivas-Ubach, A. Ecological metabolomics: Overview of current developments and future challenges. Chemoecology 2011, 21, 191-225. [CrossRef]

80. Nielsen, J.; Jewett, M.C. The role of metabolomics in systems biology. In Metabolomics; Springer: Berlin/Heidelberg, Germany, 2007; pp. 1-10.

81. Legrand, C.; Rengefors, K.; Fistarol, G.O.; Graneli, E. Allelopathy in phytoplankton-biochemical, ecological and evolutionary aspects. Phycologia 2003, 42, 406-419. [CrossRef]

82. Arzul, G.; Gentien, P. Allelopathic interactions among marine microalgae. In Algal Cultures, Analogues of Blooms and Applications; Subba Rao, D.V., Ed.; Science Publishers: Enfield, NH, USA, 2006; pp. 131-161.

83. Thacker, R.W.; Nagle, D.G.; Paul, V.J. Effects of repeated exposures to marine cyanobacterial secondary metabolites on feeding by juvenile rabbitfish and parrotfish. Mar. Ecol. Prog. Ser. 1997, 21-29. [CrossRef]

84. Waggett, R.J.; Tester, P.A.; Place, A.R. Anti-grazing properties of the toxic dinoflagellate Karlodinium veneficum during predator-prey interactions with the copepod Acartia tonsa. Mar. Ecol. Prog. Ser. 2008, 366, 31-42. [CrossRef]

85. Wood-Charlson, E.M.; Hollingsworth, L.L.; Krupp, D.A.; Weis, V.M. Lectin/glycan interactions play a role in recognition in a coral/dinoflagellate symbiosis. Cell. Microbiol. 2006, 8, 1985-1993. [CrossRef] [PubMed]

86. Mafra, L.L., Jr.; Nagai, S.; Uchida, H.; Tavares, C.P.; Escobar, B.P.; Suzuki, T. Harmful effects of Dinophysis to the ciliate Mesodinium rubrum: Implications for prey capture. Harmful Algae 2016, 59, 82-90. [CrossRef] [PubMed]

87. Ojamäe, K.; Hansen, P.J.; Lips, I. Mass entrapment and lysis of Mesodinium rubrum cells in mucus threads observed in cultures with Dinophysis. Harmful Algae 2016, 55, 77-84. [CrossRef] [PubMed]

88. Papiol, G.G.; Beuzenberg, V.; Selwood, A.I.; MacKenzie, L.; Packer, M.A. The use of a mucus trap by Dinophysis acuta for the capture of Mesodinium rubrum prey under culture conditions. Harmful Algae 2016, 58, 1-7. [CrossRef] [PubMed]

89. Richlen, M.; Barber, P. A technique for the rapid extraction of microalgal DNA from single live and preserved cells. Mol. Ecol. Resour. 2005, 5, 688-691. [CrossRef]

90. Guindon, S.; Dufayard, J.-F.; Lefort, V.; Anisimova, M.; Hordijk, W.; Gascuel, O. New algorithms and methods to estimate maximum-likelihood phylogenies: Assessing the performance of PhyML 3.0. Syst. Biol. 2010, 59, 307-321. [CrossRef] [PubMed] 
91. Lefort, V.; Longueville, J.-E.; Gascuel, O. SMS: Smart Model Selection in PhyML. Mol. Biol. Evol. 2017, 34, 2422-2424. [CrossRef] [PubMed]

92. Huelsenbeck, J.P.; Ronquist, F. MRBAYES: Bayesian inference of phylogenetic trees. Bioinformatics 2001, 17, 754-755. [CrossRef] [PubMed]

93. Bowers, H.A.; Tomas, C.; Tengs, T.; Kempton, J.W.; Lewitus, A.J.; Oldach, D.W. Raphidophyceae (chadefaud ex silva) systematics and rapid identification: Sequence analyses and real-time PCR assays. J. Phycol. 2006, 42, 1333-1348. [CrossRef] [PubMed]

94. Johnson, C.H.; Ivanisevic, J.; Siuzdak, G. Metabolomics: Beyond biomarkers and towards mechanisms. Nat. Rev. Mol. Cell Biol. 2016, 17, 451-459. [CrossRef] [PubMed]

95. Johnson, M.D.; Tengs, T.; Oldach, D.W.; Delwiche, C.F.; Stoecker, D.K. Highly divergent SSU rRNA genes found in the marine ciliates Myrionecta rubra and Mesodinium pulex. Protist 2004, 155, 347-359. [CrossRef] [PubMed]

96. White, T.J.; Bruns, T.; Lee, S.; Taylor, J. Amplification and direct sequencing of fungal ribosomal RNA genes for phylogenetics. PCR Protoc. Guide Methods Appl. 1990, 18, 315-322.

97. Scholin, C.A.; Herzog, M.; Sogin, M.; Anderson, D.M. Identification of group-and strain-specific genetic markers for globally distributed Alexandrium (Dinophyceae). II. Sequence analysis of a fragment of the LSU rRNA gene. J. Phycol. 1994, 30, 999-1011. [CrossRef]

98. Olenina, I. Biovolumes and size-classes of phytoplankton in the Baltic Sea. HELCOM Balt. Sea Environ. Proc. 2006, 106, 1-144.

99. Guillard, R.; Hargraves, P. Stichochrysis immobilis is a diatom, not a chrysophyte. Phycologia 1993, 32, $234-236$. [CrossRef]

100. Mountfort, D.O.; Suzuki, T.; Truman, P. Protein phosphatase inhibition assay adapted for determination of total DSP in contaminated mussels. Toxicon 2001, 39, 383-390. [CrossRef]

(C) 2018 by the authors. Licensee MDPI, Basel, Switzerland. This article is an open access article distributed under the terms and conditions of the Creative Commons Attribution (CC BY) license (http:/ / creativecommons.org/licenses/by/4.0/). 